\title{
Comparative Analysis of Persuasive Strategies in English Social and Commercial Advertisements
}

Somayyeh Motallebi, Davud Kuhi

English Language Department, Maragheh Branch, Islamic Azad University, Maragheh, Iran

E-mail: somaiyeh.motallebi@yahoo.com

English Language Department, Maragheh Branch, Islamic Azad University, Maragheh, Iran davudkuhi@yahoo.com

\section{ABSTRACT}

The purpose of this paper is to investigate the difference between 35 social and 35 commercial ads that gathered through the internet. Socio-pragmatic strategies that used in ads including Grice (1975) cooperative principle (CP), Leech (1983) politeness principle (PP) and Searle (1970) speech act to persuade persuadees. The findings revealed that cooperative principles are mostly observed in both kinds of advertisement. And there was significant difference in social and commercial ads. This paper indicates that cooperative principles appear to be the more powerful constraints in advertising discourse than politeness principles. As well politeness principles are to be applied in commercial ads significantly more than in social ads. Speech acts are similarly observed in social and commercial ads and they are almost never violated.

Key Words: Advertisement; Persuasion; Persuasive Language; Speech act; Cooperative principle; Politeness; Politeness principle; Observing; Violating; Foregrounding vs. backgrounding

\section{Council for Innovative Research}

Peer Review Research Publishing System

\section{Journal: Journal of Advances in Linguistics}

Vol.5, No 2

editor@cirjal.com

www.cirjal.com, www.cirworld.com 


\section{INTRODUCTION}

Goddard (2002) said that advertising is all around us. People are exposed to them from a variety of sources and in a variety of forms. They receive them from different channels as radio, TV, newspapers, internet, etc. Many people, including the advertisers themselves, claim "advertising has become one of the most important influences in our lives" (Dyer, 1982, p. 1).

Advertisements are messages that designed to promote products, services, or ideas (Tahririan, 1995). The main function of advertising is to persuade people to buy the product, but also it includes entertain, amuse, inform, misinform, worry or warn (Cook, 2001). Advertising discourse is based on persuasion. According to Schmidt and Kress (1986, as cited in Peterkova, 2008) persuasion is a voluntary change in someone's attitudes, beliefs or behavior through the transmission of a message. Cook (1992) identifies advertisements as a kind of discourse.

Following Lakoff (1982), a discourse is considered persuasive when "the intent to persuade is recognized explicitly as such by at least one party to the discourse" (p. 28). In the case of advertising, both parties recognize this intention.

Pragmatic focuses on the aspects of language structures and language principles. It studies the relationship between language and context that are encoded in the structure of language (Levinson, 1983). From the point of view of pragmatics, advertising discourse is based on implicature (Cook, 1992). The implicature enables the advertiser to hide his or her persuasive intention with which he or she enters advertising communication. This study has mainly used a pragmatic framework to describe and analyze the data. This framework is theoretically supported by the concepts of speech acts theory, Gricean cooperative maxims and Leech politeness maxims.

Cooperative principles consist of quantity maxim, quality maxim, relation maxim and manner maxim. By flouting one maxim advertiser can attract the consumer's attention.

Leech $(1995$, p. 79$)$ stresses that PP is a necessary complement to CP, which "rescues the CP from serious trouble". Leech $(1983$, p. 82) maintains that people often break the CP for politeness reasons. In other words, "to maintain the social equilibrium and the friendly relations which enable us to assume that our interlocutors are being cooperative in the first place". Leech proposes a set of politeness maxims, such as the tact maxim, generosity maxim, approbation maxim, modesty maxim, agreement maxim, sympathy maxim.

Speech act means that language users make utterances in order to perform certain actions. The term speech act includes three simultaneous acts: locutionary act that is related to the literal meaning of the utterance. Illocutionary act is produce to communicate a certain intention, and perlocutionary act that is the consequential effect of an utterance what is achieved (Austin, 1962). Following Austin, Searle (1970) distinguishes five types of acts performed via speech: 1. assertives, 2. directives, 3. commissives, 4. expressives, and 5. declarations.

Hardin (2001) studied the application of persuasive discourse in Spanish language advertising. This investigation analyzed pragmatic ways in which Spanish try to achieve persuasion in television advertising. The author applies pragmatic principles to commercials for products and services from three countries that including, Chile, Spain, and the United States. The most representative variables included speech acts, implicatures, politeness, violations of Grice's Maxims, and speaker considerations. Research on advertising discourse is limited. Most of the studies on advertising concentrate on one or a few component of advertising and ignore the others. There are also studies which describe the pictures of advertising without paying any attention to language. Describing advertising discourse is more complex. Thus it needs to be analyzed more. Against all challenges, as no research has been found by the researcher on the comparison of persuasive strategies used in social and commercial ads in English language, this study is going to analyze some English social and commercial ads in order to illustrate the persuasive strategies that they share in common. The analysis is based on a sample of 70 display ads, 35 commercial and 35 social ones. Based on the background of the study above, the study focuses on the following problems:

1. What are the persuasive strategies used in English social and commercial ads?

2. How are the persuasive strategies used in English social and commercial ads?

\section{METHODOLOGY}

To carry out the comparison between the advertisements, a sample of 35 social and 35 commercial ads, 70 ads in total, were selected from among a large corpus of advertisements through the internet. The data collection was done in June and July of 2013. Majority of collected ads were extracted from Google Search Engine. Then, Grice's (1975) model of cooperative principle (CP), Leech's (1983) model of politeness principle (PP), and Searle's (1970) model of speech act were used as criteria for data analysis. This required an individual and manual analysis of all the maxims and principles present in the selected ads.

The result of this study was confirmed by the second rater in order to ensure the inter-rater reliability $(0.89)$ of the assessment.

\section{RESULTS AND DISCUSSIONS}

According to bottom table cooperative principles are mostly observed in both kinds of advertisement, whether social or commercial ads. In some cases these principles are violated but they have never been backgrounded in advertisements. However, while social ads are the first in observance of cooperative principles, commercials are first in violation of these 
principles. That means cooperative principles are never ignored in advertisement, they are represented in ads, either observed or violated. This is in the same line with Coulthard's (1985) idea that there are occasions when speakers decide to unboastfully violate a maxim, he may lie, he may give information that has lack of relevance, or may provide utterances that can be later realized as ambiguous. Moreover, there are much more important occasions when a speaker breaks a maxim for certain reasons such as he faces a clash between two maxims, and that would make it impossible for the persuader to be as specific as he should be and still his speech would lack adequate evidence, perhaps he chose to violate a maxim, that is to say he may blatantly fail to fulfill it. In such cases, these maxims provide a basis for the persuadee to understand what is conversationally being implicated.

In the case of politeness principles, they are mostly, but not always, backgrounded either in social or commercial ads. Moreover, observance or violation of politeness principles occurs in commercial ads more than in social ads. This variation in politeness principle appliance in social and commercial ads lends support to Leech's (1983) idea that not all of the maxims are equally important. Politeness principle is mostly backgrounded in social ads. Also, it is backgrounded in the commercials in order to achieve to their aim. Considering speech acts, most of the time, they are backgrounded in ads. Sometimes, speech acts are observed in social and commercial ads and they are almost never violated.

It can be claimed that the advertisement discourse is an illocutionary act which is associated with the perlocutionary act of persuasion, an act that its aim is to get persuadees to accept an idea (Searle, 1970) or purchase a product. Therefore, it works in both social and commercial ads similarly.

The researcher of the present study claims that taking advantage of both cooperative and politeness principles are necessary devices in advertisement, in general. As well enjoying speech acts of persuasion are of vital devices in advertisement discourse, which lends support to Hardin's (2001) findings who asserted that the most representative variables in language of advertisement included speech acts, implicatures, politeness, violations of Grice's Maxims, and speaker considerations.

Table 3 Pragmatic Principles and Speech Acts in Social and Commercial Ads

\begin{tabular}{|c|c|c|c|c|c|c|}
\hline & \multicolumn{2}{|c|}{ Observed } & \multicolumn{2}{|c|}{ Violated } & \multicolumn{2}{|c|}{ Backgrounded } \\
\hline & SA & CA & SA & $\mathrm{CA}$ & SA & $\mathrm{CA}$ \\
\hline Cooperative Principles & 119 & 109 & 21 & 31 & 0 & 0 \\
\hline Politeness Principles & 33 & 51 & 23 & 32 & 154 & 128 \\
\hline Speech Acts & 76 & 69 & 1 & 1 & 98 & 105 \\
\hline
\end{tabular}

\subsection{Cooperative Principles in Social and Commercial Ads}

The maxims of cooperative principles are quantity Maxim (make your contribution as informative as is required, do not make your contribution more informative than is required), quality Maxim (do not say what you believe to be false, do not say that for which you lack adequate evidence), relation maxim (be relevant) and manner maxim (avoid obscurity of expression, avoid ambiguity, be briefly and be orderly).

\subsubsection{Quantity and Quality Maxims in Ads}

Some of the advertisements tend to violate the maxim of quantity because their "contribution is not as is required" (Grice, 1975 , p. 58). In quality maxim, advertisements will state mainly the strong points of the products and services to help persuadees know about them and trust them (Grice, 1975).

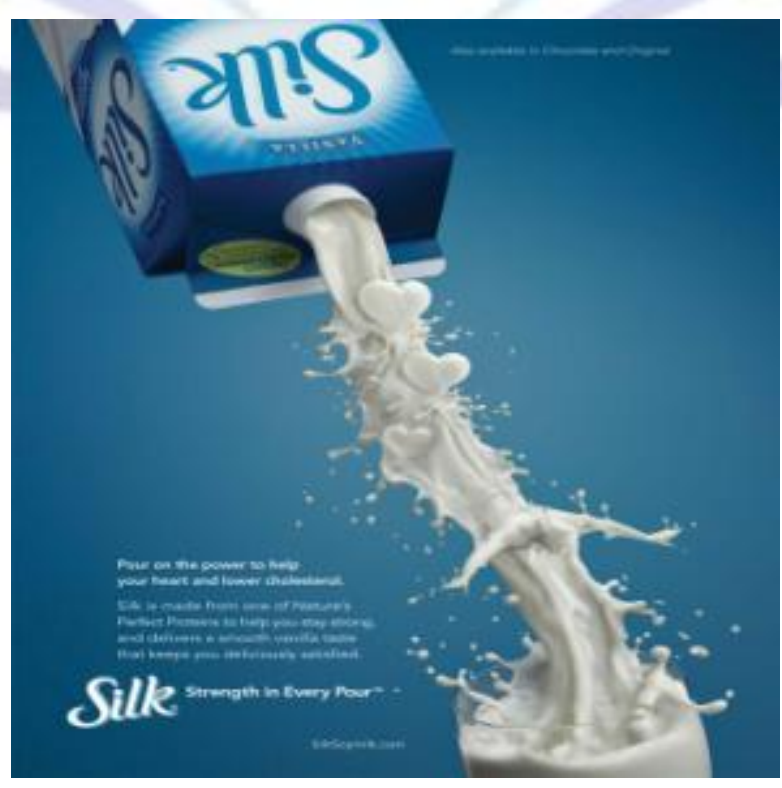


CA25.

Pour on the power to help your heart and lower cholesterol.

Silk is made from one of Nature's perfect Proteins to help you stay strong, and delivers a smooth vanilla taste that keeps you deliciously satisfied.

Silk strength in every pour.

Observing a maxim is related to the meaning that is literally spoken/written (Mey, 2001). The observance of the quantity and quality maxims, here, is achieved by providing product name and its distinctive qualities. The persuader considers important and adequate amount of fact about the product. It communicates the product name, plus he highlights the fact that the product is perfect for your heart health and lowering cholesterol. It is also shown in the picture by pouring milk with some hearts and an athlete diving in milk that resembles health and strength.

In this ad, assertives contribute towards the observance of the CPs. Therefore, these attend to enhance persuasive potential of the ad. Also, these maxims are violated in the following sample ad:

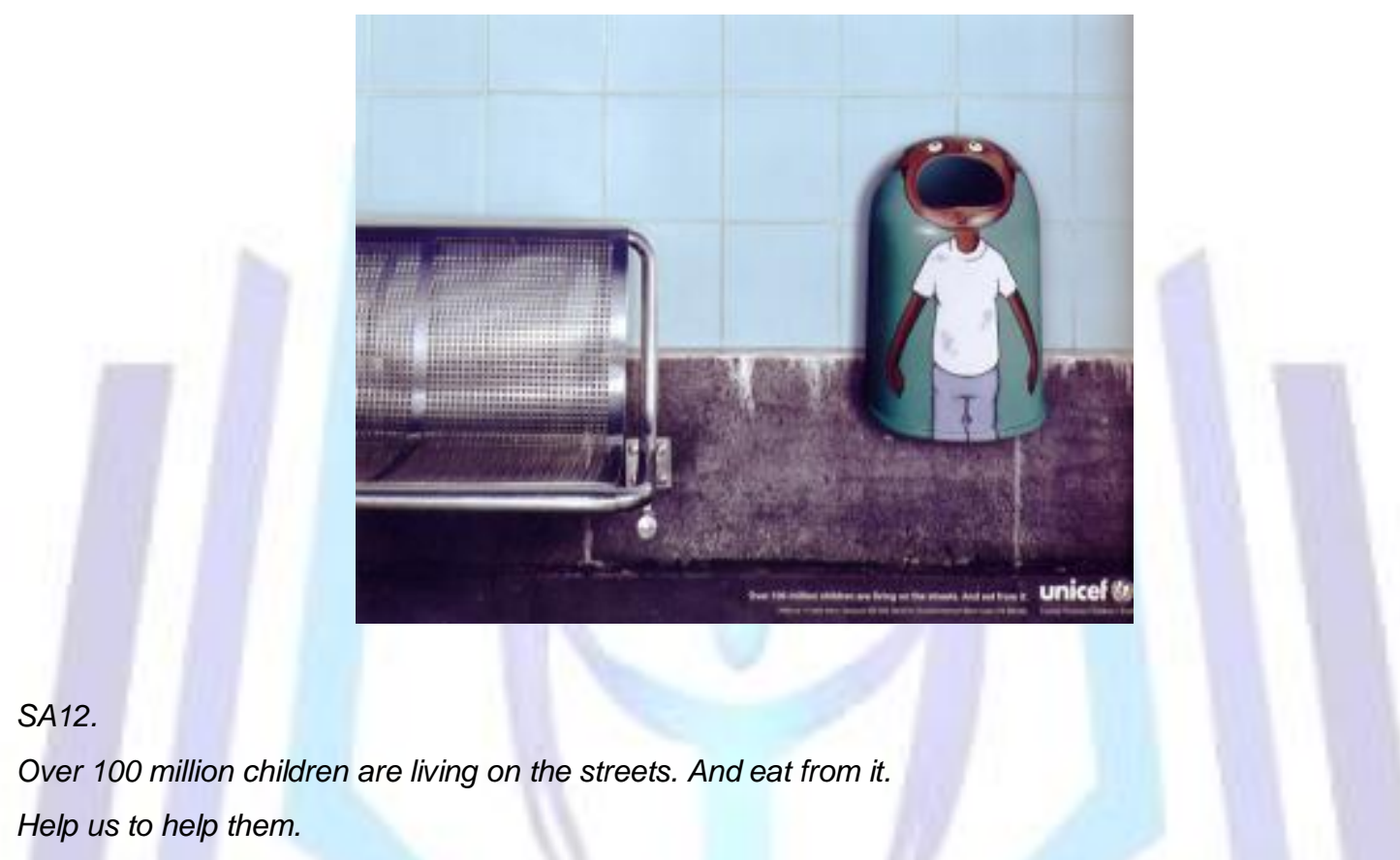

Violating a maxim is to flout a maxim intentionally or unintentionally and therefore transform a different meaning than what is literally spoken or written (Mey, 2001). This ad violates the maxims of quantity and quality due to lack of adequate amount of information. The violation of these maxims might also be due to the ambiguity and vagueness: "And eat from it". The referents of the pronominal expressions are derivable from the situational context adopted by the advertising situation.

And they contribute towards the maximization of the persuasive potential of the ad.

\subsubsection{Relation Maxim in Ads}

This is the most significant advertisement designing, that mostly employs natural association to pass useful information and to touch persuades, for example:

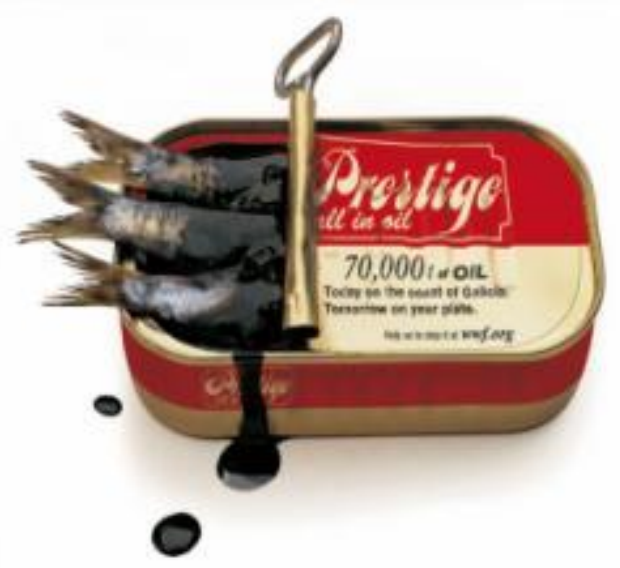




\section{SA3.}

\section{0,000 t of OIL}

Today on the coast of Gallicia.

Tomorrow on your plate.

Help us to stop it at wwf.org

The assertives contribute towards the observance of the CPs.

\subsubsection{Manner Maxim in Ads}

The observance of the maxim of manner in most of the social ads might be because the persuader tries to affect the persuaders with direct speech. The reason for violation of the manner maxim in commercial ads, on the other hand, might be because its violation enables the advertisement to observe other principles applied in communication. However, Grice (1975) did not believe that all people should constantly follow these maxims. Instead, he found it interesting when they were violated (either purposefully or unintentionally) by speakers, which would imply some other hidden meaning. And the importance was in what was not said. An example for violation of the maxim of manner is represented in the following ad:

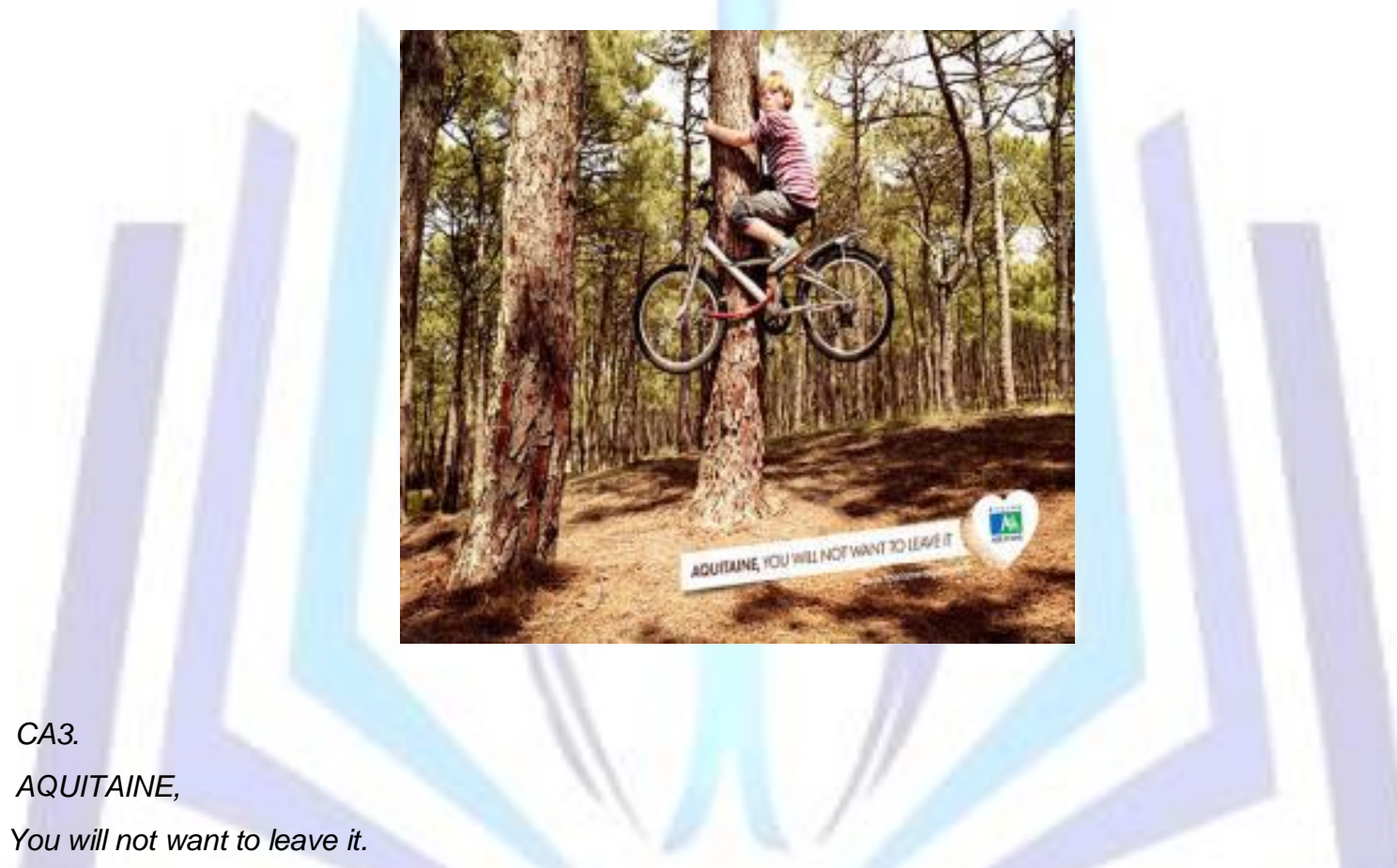

This ad violates the maxim of manner due to the lack of perspicacious information about this place. Also, assertive contributes to the observing of cooperative principle.

\subsection{Politeness Principles in Social and Commercial Ads}

Politeness principle is affected by some maxims such as tact maxim which minimizes cost to other and maximizes benefit to other; generosity maxim which minimizes benefit to self and maximizes cost to self; approbation maxim which minimizes dispraise of other and maximizes praise of other; modesty maxim which minimizes praise of self and maximizes dispraise of self; agreement maxim which minimizes disagreement between self and other, and maximize agreement between self and other; sympathy maxim which minimizes antipathy between self and other and maximizes sympathy between self and other (Leech, 1983). For example;

\subsubsection{Tact Maxim and Generosity Maxim in Ads}




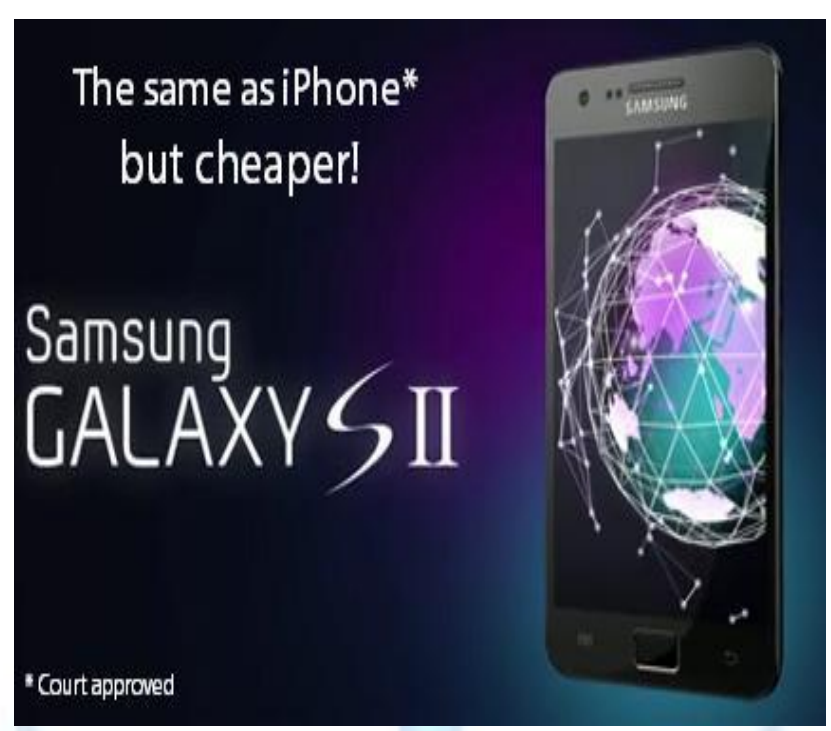

CA22.

The same as iPhone but cheaper!

Samsung Galaxy SII

In this ad, Samsung Company, first, contributes towards the maximization of its cost by producing a high-tech cellphone as the same as iPhone's last and best model and stating this statement "The same as iPhone". Thus, it observes the generosity maxim. Following observance of generosity maxim, the ad observes tact maxim by "but cheaper" statement. Therefore, it enhances persuasive potential of ad.

\subsubsection{Approbation Maxim in Ads}

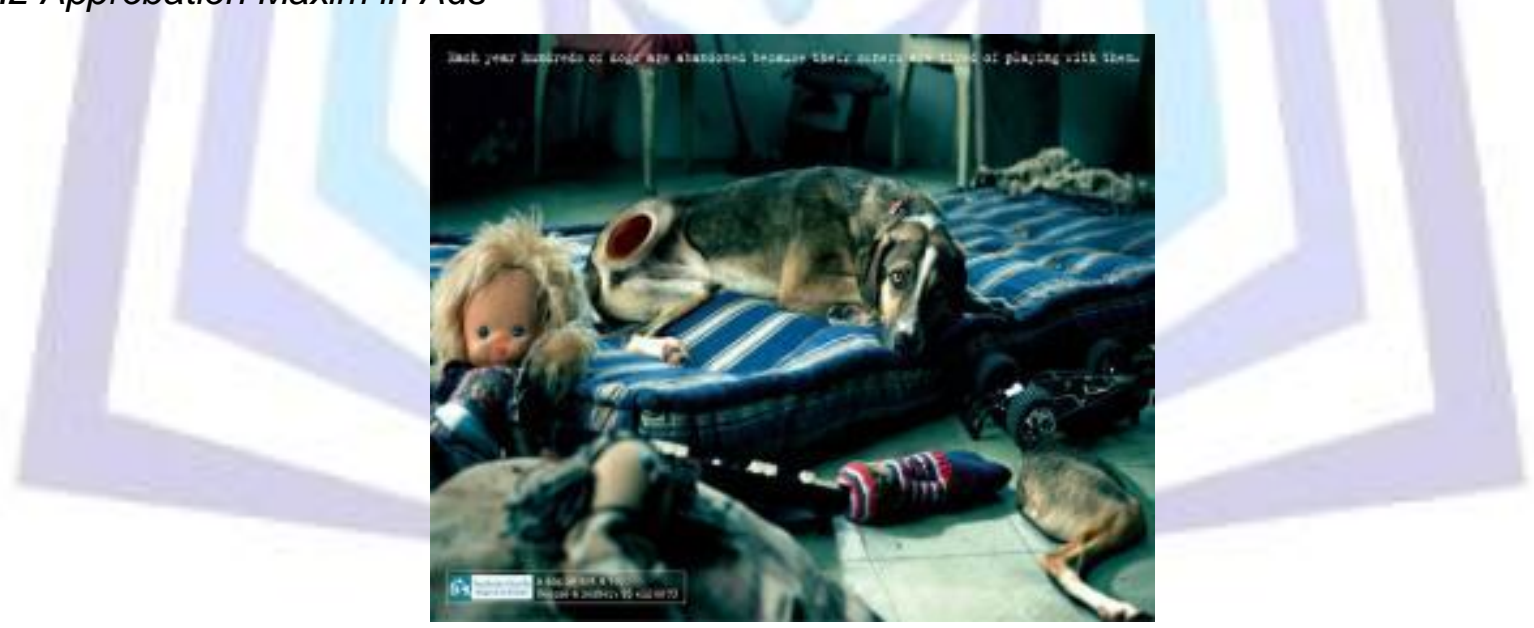

SA15.

Each year hundreds of dogs are abandoned because their owners are tired of playing with them

A dog is not a toy. Become a member.

In the social ad above, Approbation maxim is violated by dispraising dog owners and criticizing them for their non-sense behavior with their dogs as toys that can be thrown out when they tired of them.

Direct speech used in this ad enhances the persuasive potential of the advertising message.

Another example about the observance of this maxim: 


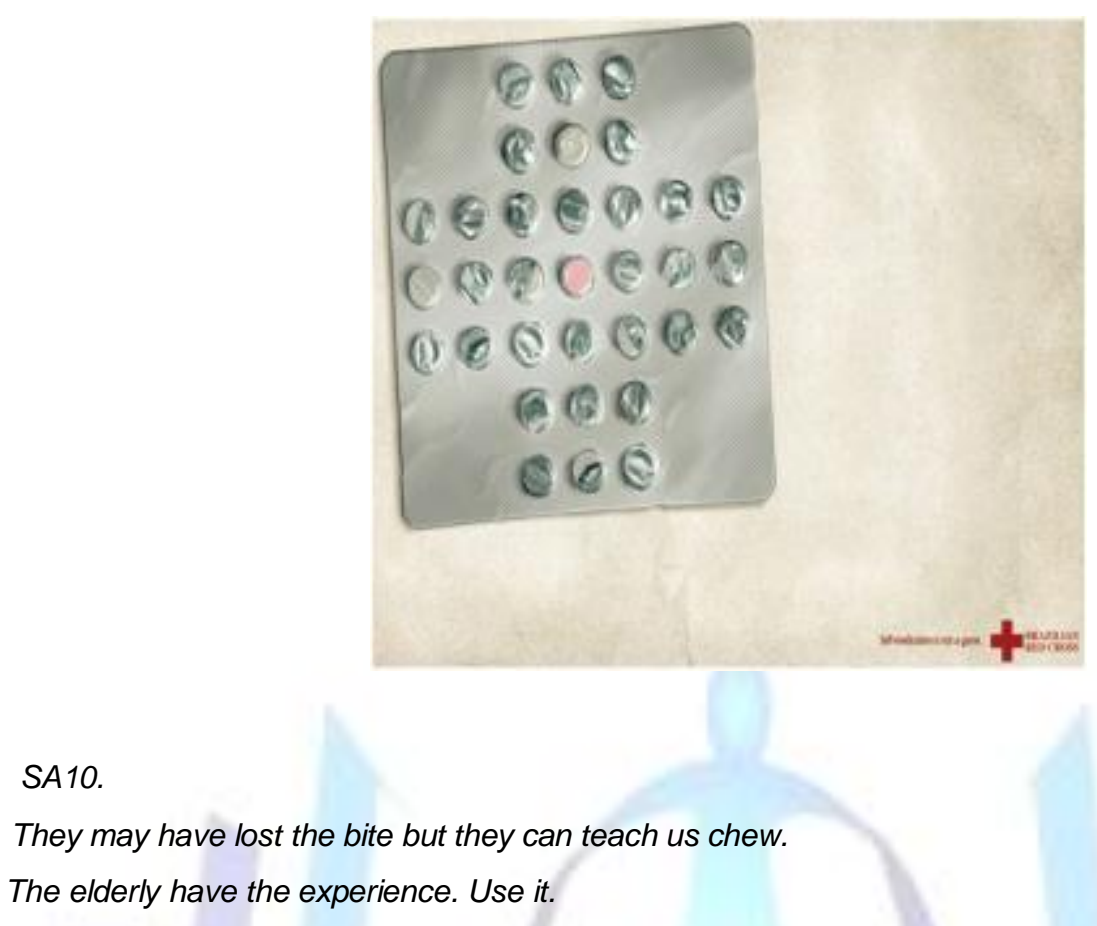

This ad observes the Approbation maxim as far as the maximization of old people praise is concerned.

\subsubsection{Modesty Maxim in Ads}

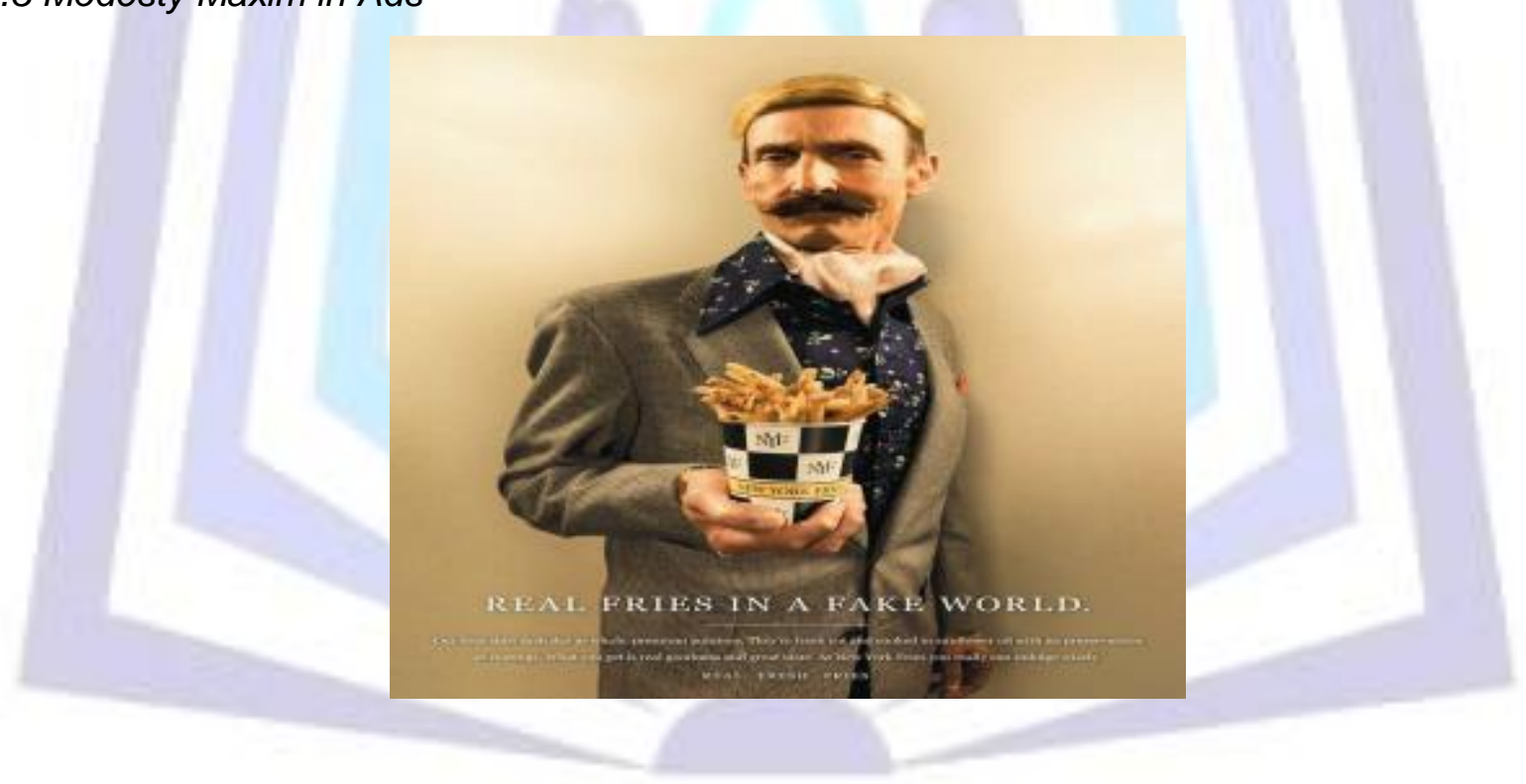

CA19.

Real fries in a fake world.

Our fries start each day as whole, premium potatoes. They're fresh cut and cooked in sunflower oil with no preservatives or coatings. What you get is real goodness and great taste. At New York Fries you really can indulge wisely.

Real, Fresh, Fries.

As you see in the example above, the violation of Modesty maxim results from maximizing the persuader's costs and praise, e.g., "Our fries start each day as whole, premium potatoes", and "They're fresh cut and cooked in sunflower oil with no preservatives or coatings".

Assertives, expressives, and commissives represent indirect speech acts that enable the persuaders to violate the Modesty Maxim and therefore enhance potential persuasion power of the ad.

\subsubsection{Agreement Maxim in Ads}




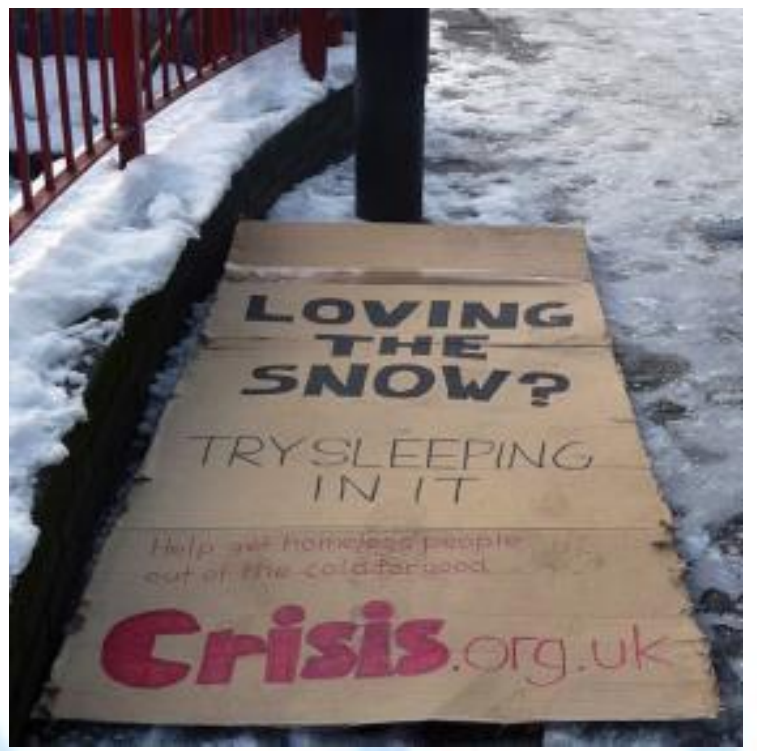

SA19.

Loving the snow?

Try sleeping in it

Help get homeless people out of the cold for good

Sharing one's problem has an impact on the maximization of agreement between the persuader and the persuadee, hence the observance of the Agreement Maxim in some of the ads like this.

Direct speech used in this ad presents the maxim of agreement and it enhances persuasive potential of ad.

\section{2.5 Sympathy Maxim in Ads}

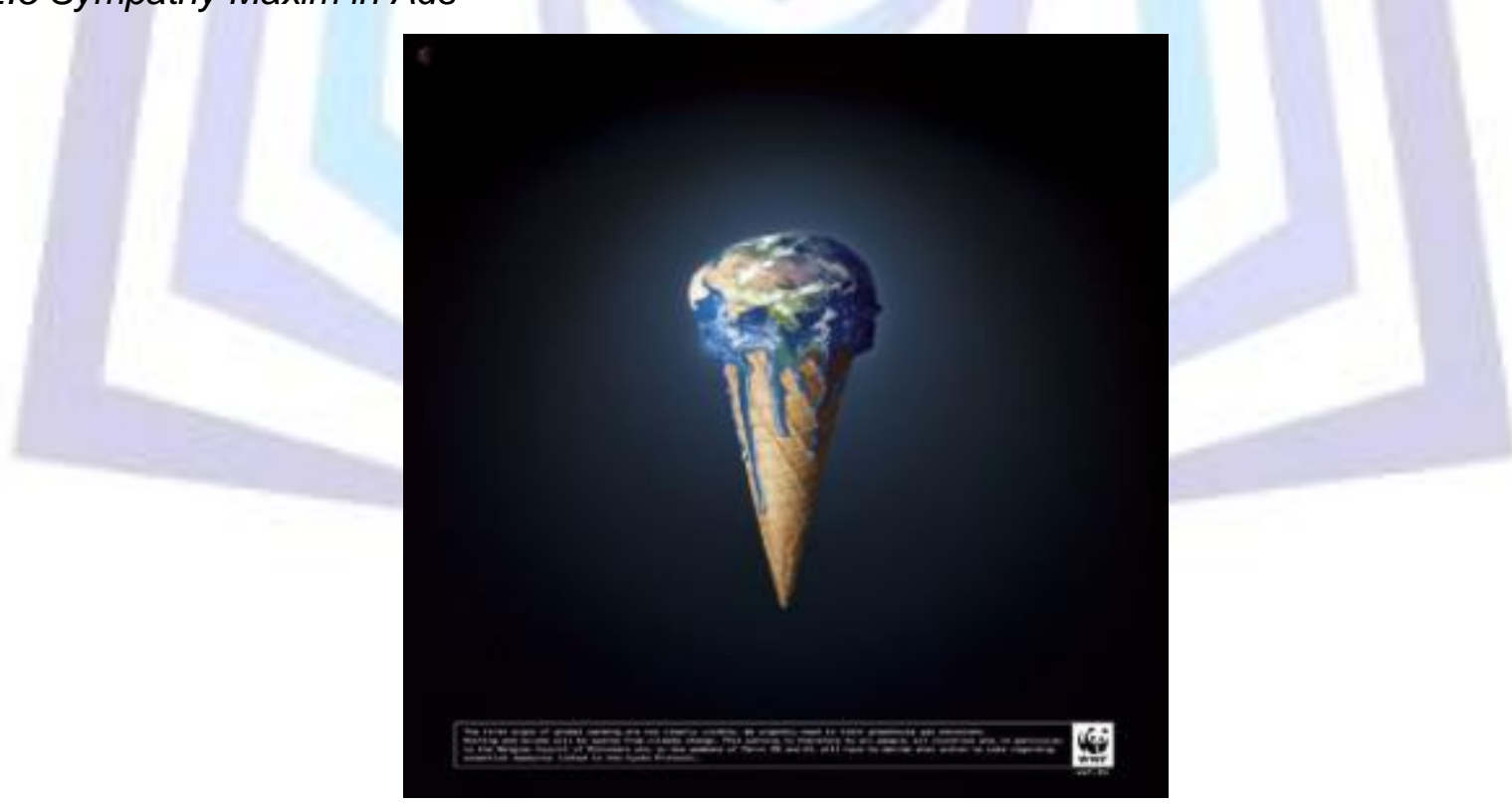

SA2.

The first signs of global warming are now clearly visible. We urgently need to limit greenhouse gas emissions. Nothing and no one will be spared from climate change. This warning is therefore to all people, all countries, and in particular to the Belgian Council of ministers who, on the weekend if March 20 and 21, will have to decide to what action to take regarding essential measures linked to the Kyoto Protocol.

In this ad, the persuader's worried statements and expressions illustrate her/his high degree of interest in the topic being discussed. Moreover, these statements enable her/his to communicate that she/he sympathizes with the earth's global warming, hence the observance of the sympathy maxim. 
Sympathy maxim, as another type of persuasion, which appeals to the reader's senses and emotions, is used in this ad for more persuasion.

\subsection{Speech Acts in Social and Commercial Ads}

According to Searle's (1970) approach, speech acts can be classified into five categories: assertives, that represent the speaker's belief about the truth of a proposition; directives, that cause the hearer to take a particular action; commissives, that commit a speaker to some future action; and expressives, that express the speaker's attitudes and emotions towards the proposition; declarations, that change the reality according to the proposition of the declaration.

\subsubsection{Assertives in Ads}

The prevailing speech act type is represented by assertives. Assertives enable the persuaders to observe as well as violate the CP and PP in order to provide product information and to maximize the product praise. Assertives, usually take the form of claims (Dayag, 2001). And it includes scientific explanation in assertives, it is safe to say that the claims are not verifiable, and therefore do not carry much weight. But this probably is what makes ads persuasive in nature. Example:

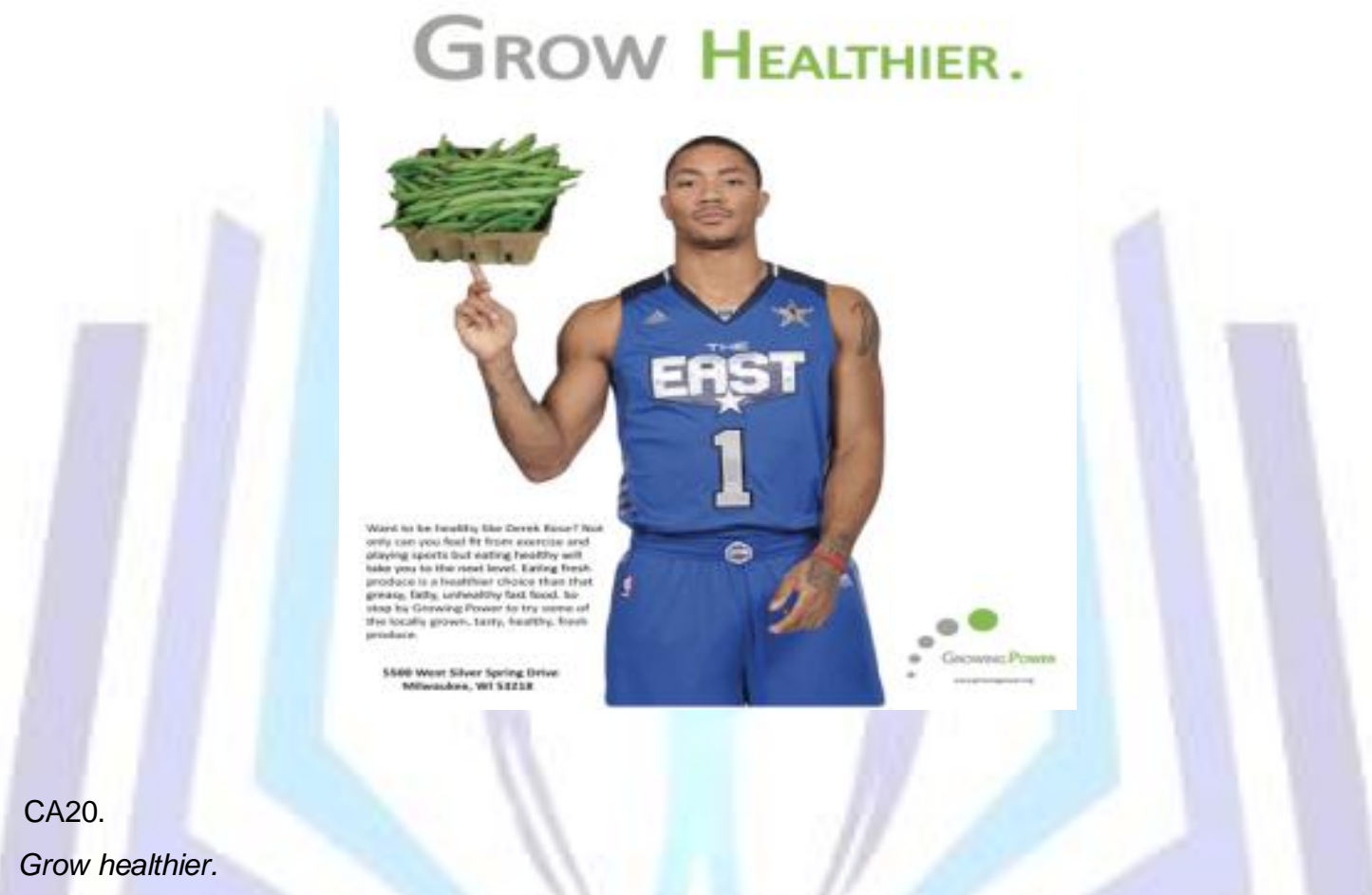

Want to be healthy like Derek Rose? Not only can you feel from exercise and playing sports but eating healthy will take you to the next level. Eating fresh products is a healthier choice than that greasy, fatty, unhealthy fast food. So stop by Growing Power to try some of the locally grown, tasty, healthy, fresh produce.

Assertives contribute towards the observance of the CPs. Therefore, by presenting true (quality maxim), enough (quantity maxim) and related (relative maxim) information the persuader attends to enhance persuasive potential of the ad.

\subsubsection{Directives in Ads}

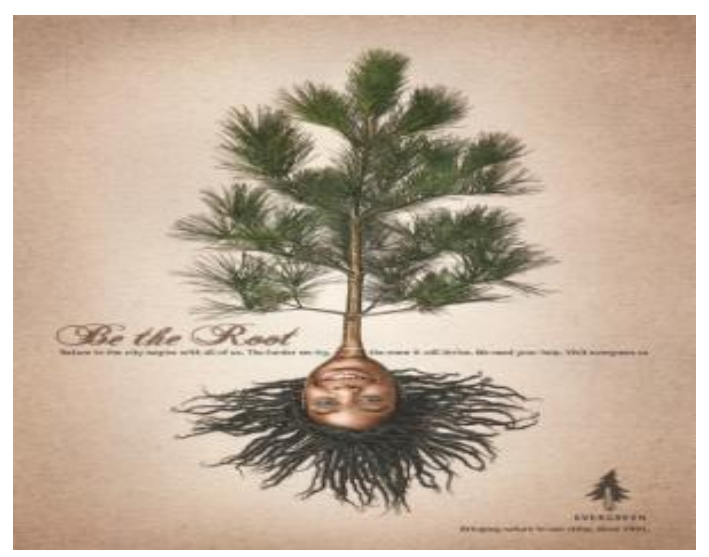




\section{SA32}

Be the root

Nature in the city begins with all of us. The harder we try, the more it will thrive. We need your help. Visit evergreen.ca

They contribute towards the maximization of the benefits to the persuadee, e.g. "Be the root", and "Visit evergreen.ca". Since the directives appeal for the persuadee to engage in a certain beneficial action, they are interpreted as acts maximizing the benefits to the persuadee. The observance of directives is somewhat pervasive in both social and commercial ads.

Thanks to direct speech used in this ad, it enhances the persuasive potential and credibility of the advertising message invites the persudees to visit their website to get more and incredible information about the campaign.

\subsubsection{Commissives in Ads}

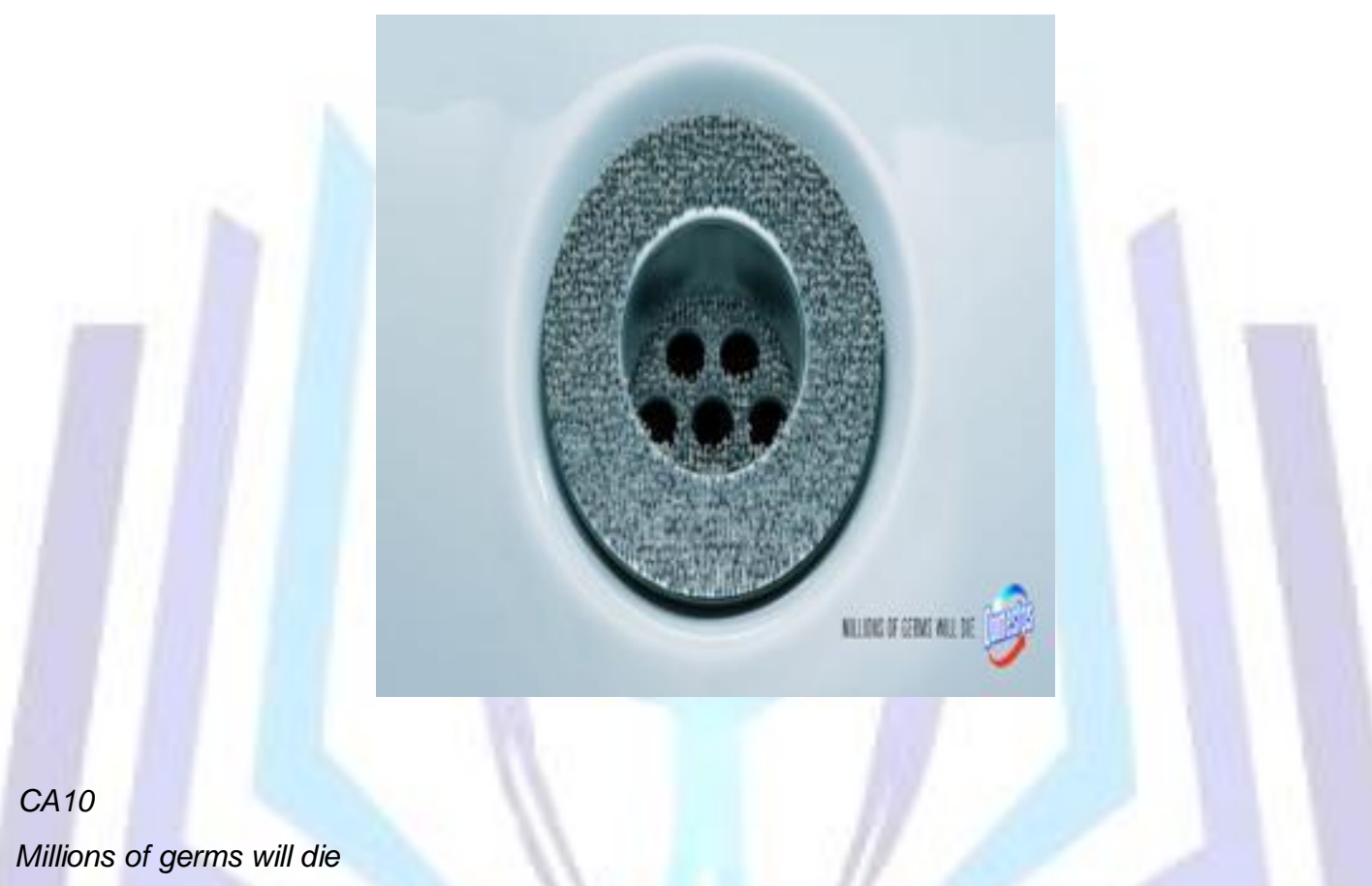

As you notice, there is a commissive speech act in the ad above. It is found where the persuader promises death of germs. The promise is meant to maximize both the product praise and the benefits to the persuadee.

Commisive is one of the common speech acts which is being observed in social and commercial ads. While in commercial ads, common Commissive speech acts are promises, in social ads, common Commissive speech acts are threats.

Assertives and commissives represent indirect speech acts that enable the persuader to violate the modesty maxim and mostly participate in observing the tact maxim to enhance potential persuasion power of the ad.

\subsubsection{Expressives in Ads}

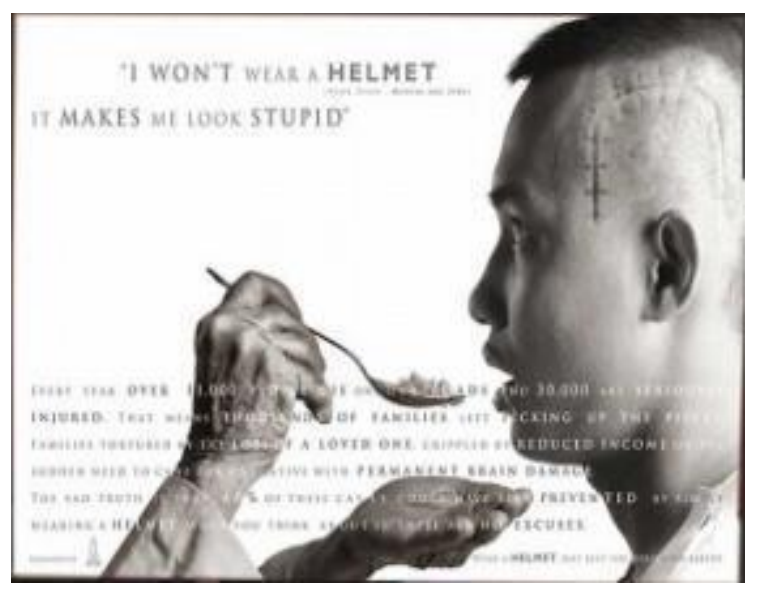


SA20.

"I won't wear a helmet

It makes me look stupid"

Every year over 11,000 people die on our roads. And 30,000 are seriously injured. That means thousands of families left picking up the pieces families tortured by the loss of a loved one. Crippled by reduced income or the sudden need care for an alternative with permanent damage.

The sad truth is that $40 \%$ of these cases could have been prevented by simply wearing a helmet. When you think about it there are no excuses.

Wear a helmet, not just for your own safety.

In the sample ad above, the expressive is used in the confessions, where the persuaders need to express their concerns in order to make their confessions as authentic as possible, e.g."Every year over 11,000 people die on our roads", "And 30,000 are seriously injured", etc. Consequently, the expressive contributes towards the maximization of the persuadees' cost and dispraise.

Expressive speech acts are common in commercial ads because persuaders often praise and tend to create a sense of agreement with the persuadees in the ads, but they are rare in social ads because they do have an informative nature talking about the society's problem rather than the persuadees' needs, feelings, and desires.

Expressive maxim, which appeals to the reader's senses and emotions, is used in this ad for more persuasion.

Declarative speech act has never been used in advertisement discourse, thus, it is not in the scope of the study.

In the present study, these persuasive devices include a preference for socio-pragmatic structures such as cooperative principles, politeness principles, and speech acts.

In most of commercial ads, (e.g. CA 1), assertives contribute towards the observance of the CPs. Since assertives enable persuader to provide true facts about the product being advertised. In other words, assertive contribute towards the maximization of the product praise. Therefore, by presenting true (quality maxim), enough (quantity maxim) and related (relative maxim) information the persuader attends to create a clear and unambiguous information (manner maxim) to enhance persuasive potential of the ad. CP is an umbrella term that groups all the phenomena of meaning recovery where pragmatic processes intervene. Since they intend to be beneficial for the persuadee, persuaders contribute towards the observance of the tact maxim. Therefore, they contribute towards the maximization of their cost and, thus, they observe the generosity and, accordingly, violate modesty maxim. Srpová (2008: 117-118) says "The violation is determined by the effort to increase the attractivity of an advertised message".

In most of social ads, however, (e.g. SA 4), although the quantity maxim is violated, it successfully passes the related information to the audience in an obvious manner and thus effectiveness of the ad is not on the quantity but quality observation. These two maxims ( $Q n$ and QI) work in competition, i.e. the amount of information the speaker gives is limited by his wish to avoid telling an untruth. In advertising this has to be interpreted as: the strongest claim, there is evidence for will be made. These ads serve as direct speech act that violate the Approbation maxim, because in SA persuader uses direct maxim to give information about society problems and speak about ignorance of people in society problems. Moreover, relative and manner maxims are represented by assertive speech act and they contribute towards the maximization of the persuasive potential of the ad. The reason for this action is that persuader wants to has effective interaction with persuadee. The persuader attends to create more agreement between persuader and persuadee (agreement maxim) and therefore a persuasive environment in order to establish the appropriate solidarity and distance level with the persuadee.

Direct speech used in both of social and commercial ads, since these function as a device for attracting the persuadee's attention by impeding their freedom to act. (e.g. SA 18), presents the maxim of modesty because persuader wants to show dispraise of his action to attract the attention of others. And the presentation of both directive and commissive speech act enhance the persuasive potential and credibility of the advertising message which clearly invites persuadee to help the campaign. According to (Cook, 1992) the advertisements features include assert, accuse, warn, inform, claim, give directions, offer, promise, praise, require and finally buying the product. Finally, the aim of these analyses is based on persuasive people to buy the product or accepting a social idea.

\subsection{CONCLUSION}

The results of the present study may be summarized by pointing out, cooperative principles are mostly observed in both kinds of advertisement and there was significant difference in appliance of these principles in social and commercial ads. That means cooperative principles are vital in advertisement discourse. In such cases, the conversational maxims provide a basis for the persuadee to understand what is conversationally being implicated. In this, as what Leech (1983) believes that the four maxims have the function of regulating what it is advertised so that it contributes to some assumed illocutionary goals. 
The researcher indicates that cooperative principles appear to be the more powerful constraints in advertising discourse than politeness principles. As well politeness principles are to be applied in commercial ads significantly more than in social ads. With regard to the Politeness Principle, these maxims are the least frequently used maxims in both social and commercial ads. According to Leech (1983), PP relates to the relationship between two participants that called self and other. So far, he explains that the importance of showing politeness to the persuadee varies.

Speech acts are similarly observed in social and commercial ads and they are almost never violated. Thus, it confirmed Searle's (1970) idea that the advertisement discourse is an illocutionary act which is associated with the perlocutionary act of persuasion, an act that objective is to get persuadees to accept an idea (Searle, 1970) or purchase a product.

Finally, in terms of socio- pragmatic strategies, these strategies are necessary because advertisers know that a persuasive message needs to be under an"informative mask so that the receiver gets a delusive impression of a referential message" (Fuertes-Olivera, et al., 2001, p. 1295).

The findings of the present study have some pedagogical implications for EFL and English for specific purposes (ESP) learners and teachers as well as for researchers who work on English advertisement discourse. Also, it helps people have an objective and careful consideration before buying a product or accepting and following an especial social idea.

In the field of more research firstly, a research is suggested on vocabulary, syntactic features, and lexico-grammatical features in persuasion strategies used in social and commercial ads. Secondly, more research, therefore, is suggested on other types of advertisements such as print advertisement and multimedia advertisement. Thirdly, there is a gap, therefore, on advertisement discourse of other languages, comparing advertisement discourse of two or more countries, and also other aspects of advertisement discourse whether in English or other language such as political aspect, economical aspect, etc. In addition, the researcher strongly suggests further studies on a contrastive analysis of stylistic devices used in persuasive strategies in English social and commercial advertisements and an investigation into culture influences on persuasive strategies in English and other language advertisements.

\section{ACKNOWLEDGMENTS}

I am deeply indebted to my learned supervisor, Dr. Davud Kuhi, who never deprived me of his invaluable support, advice and attention. He taught me a lot in writing paper. I am really grateful to him.

\section{REFERENCES}

[1] Austin, J. L. (1962). How to Do Things With Words. Oxford: Oxford University Press.

[2] Brown, P. \& Levinson, S. C. (1978). "Universals in Language: Politeness Phenomena". InFortes, M. et al. (Eds.), Questions and Politeness: Strategies in Social Interaction (pp.56-289). Cambridge: Cambridge University Press

[3] Cook, G. (1992). The Discourse of Advertising. London: Routledge.

[4] Cook, G. (2001). The Discourse of Advertising. London: Routledge.

[5] Coulthard, M. (1985). An Introduction to Discourse Analysis. New York: Longman.

[6] Dayag, D. T. (2001). Persuasion as a macro-speech act. Philippine Journal of Linguistics,32(1), 53-74.

[7] Dyer, G. (1982). Advertising as communication. London: Routledge.

[8] Fuertes-Olivera, P., M. Velasco-Sacristan, A. Arribas-Bano, and E. Samaniego-Fernandez.(2001). Journal of Pragmatics, 33, 1291-1307.

[9] Goddard, A. (2002). The Language of Advertising. London: Routledge.

[10] Grice, H. P. (1975). "Logic and conversation". In Peter, C. \& Morgan, J. (Eds.), Syntax and Semantics 3: Speech Acts. New York: Academic Press. Retrieved from:http://www.wam.umd.edu/ israel/Grice75.pdf, pp. 41-58.

[11] Hardin, K.J. (2001). Pragmatics of persuasive discourse in Spanish television advertising. Dallas: University of Texas

[12] Lakoff, R. T. (1982). "Persuasive Discourse and Ordinary Conversation, With Examples from Advertising". In Tannen, D. (Ed.), Analyzing Discourse: Text and Talk. Georgetown: Georgetown University Press. Retrieved fromhttp://books.google.com/books?id=RPEaibhFqp8C\&pg=PR1\&dq=analyzing+discourse\&hl=cs\&sig=9d0XR4D 6cxviQX nM, pp. 25-42.

[13] Leech, G. N. (1995). Principles of Pragmatics. London: Longman.

[14] Leech, G. N. (1983). Principles of Pragmatics .London and New York: Longman.

[15] Levinson, S. C. (1983). Pragmatics. Cambridge: Cambridge University Press.

[16] Mey, J. L. (2001). Pragmatics. Oxford: Blackwell Publishers.

[17] Peterkova, L. (2008). Persuasive strategies in discourse of advertising. Unpublished Thesis.

Masaryk University Faculty of Arts. Retrieved on March 2012, from 
http://is.muni.cz/th/177776/ff m b1/2 Diplomka.pdf

[18] Searle, J. R. (1970). Speech Acts. As Essay in the Philosophy of Language. Cambridge: Cambridge University Press. [19] Srpová, Hana (2008). Knížka o reklamě. Ostrava: Ostravská univerzita, Filozofická fakulta.

[20] Tahririan, M. H. (1995). Reading journalistic English.Tehran, Iran: Payame Noor University

\section{APPENDIX A}

\section{Verbal Content of All Social and Commercial Ads}

\section{Social Ads}

\section{SA 1.}

Hunger kills 2.5 million children every year.

\section{SA 2.}

The first signs of global warming are now clearly visible. We urgently need to limit greenhouse gas emissions. Nothing and no one will be spared from climate change. This warning is therefore to all people, all countries, and in particular to the Belgian Council of ministers who, on the weekend if March 20 and 21, will have to decide to what action to take regarding essential measures linked to the Kyoto Protocol.

\section{SA 3.}

$70,000 \mathrm{t}$ of OIL

Today on the coast of Gallicia.

Tomorrow on your plate.

Help us to stop it at wwf.org

SA 4.

Buying certain brands of shoes contributes to child labour. Just don't do it.

SA 5.

You don't want to know what a heart attack feels like.

Find out how you can prevent it from one of the top cardiovascular hospitals in the country, Halifax Health Medical Centervisit StopHeartAttacks.org now.

SA 6.

Smoking causes blindness. Quit

SA 7.

Every breath you take will eventually destroy your future.

SA 8.

The melting arctic is under threat from oil drilling, industrial fishing, and conflict. Please help.

Save the Arctic

Donate Now

SA 9.

Don't wrap it and tap it.

Tape her and rape her.

SA 10.

They may have lost the bite but they can teach us chew.

The elderly have the experience. Use it.

SA 11.

Self-medication is not a game.

SA 12. 
Over 100 million children are living on the streets. And eat from it.

Help us to help them.

SA 13.

In town, car accidents don't just happen to cars. Slow down

SA 14.

Burning the red light results in 15 victims a day.

In town, car accidents don't just happen to cars.

SA 15.

Each year hundreds of dogs are abandoned because their owners are tired of playing with them.

A dog is not a toy. Become a member.

SA 16.

The greatest wonder of the sea is that it's still alive.

SA 17.

What goes into crisps goes into you.

Some crisps contain $33 \%$ cooking oil.

SA 18.

The par: 200,000 trees!

Building a single golf course puts thousands of trees at stake. However in southern Turkey, they are planning to build several courses simultaneously. Take action. Help us stop them.

SA19.

Loving the snow?

Try sleeping in it

Help get homeless people out of the cold for good.

SA 20.

"I won't wear a helmet

It makes me look stupid"

Every year over 11,000 people die on our roads. And 30,000 are seriously injured. That means thousands of families left picking up the pieces families tortured by the loss of a loved one. Crippled by reduced income or the sudden need care for an alternative with permanent damage.

The sad truth is that $40 \%$ of these cases could have been prevented by simply wearing a helmet. When you think about it there are no excuses.

Wear a helmet, not just for your own safety.

SA 21.

Spare parts for humans are not as original as those for cars.

Don't Drink and Drive.

SA 22.

You have no choice.

Stop on red. You can make a difference.

SA 23.

There are some kids who don't have to tide their room.

SA 24.

We don't know if there is life after death.

But we do know there is life before death.

Help us be there to the very end. 
SA 25.

Why are clouds fluffy?

If you read with your kids, you'll know more.

For information on family literacy day, as well as the answer to question, visit FamilyLiteracyDay.ca

SA 26.

Super.

That' how milk makes you feel. The calcium helps bones grow strong.

So even if you're not from krypton you can have bones of steel.

Got milk?

SA 27.

Polluted river water kills as many people as a nuclear explosion.

SA 28.

I'm glad I failed

....at suicide,

because my life is so amazing now.

SA 29.

There are 110 million active landmines on the world.

Can you spot the 2 in this ad?

SA 30.

Every child needs a family.

SA 31.

Do you know what you eat?

The DNA of genetically modified plants may contain the genes of insects, animals or even viruses. These products may potentially cause harm to your health. Look for GMD free sign on the package

SA 32.

Be the root

Nature in the city begins with all of us. The harder we try, the more it will thrive. We need your help. Visit evergreen.ca

SA 33.

We are running out of time

Act now before it's too late

SA 34.

and we keep crushing it

take care of nature

as she took care of you.

SA 35 .

Humanity and nature are one.

Follow our tips and preserve life.

\section{Commercial Ads}

CA 1.

Nature wasn't up to the challenge.

We were.

FUZE Orange Mango combines the great taste of two favorite fruits and is formulated vitamin B6, a vitamin that helps the metabolism of carbohydrates and proteins, and has vitamin A, vitamin C, and vitamin $\mathrm{E}$. 
CA 2.

Stupid might fail.

Smart doesn't even try.

Be stupid.

CA 3.

AQUITAINE,

You will not want to leave it.

CA 4.

Isn't time for some happy financial news?

Arrange your everyday banking review today.

More convenient banking NOW

CA 5.

Need flyer distribution?

We get you customers at a low cost.

Join our clientele today!

CA 6.

Feet have a lot of enemies.

Protect yourself!

CA 7.

Is heartburn too much for your medication?

TUMS is safely there in seconds

Quantum speed

Nothing works faster

CA 8.

Continuous quality is quality you trust

Coca. Cola

"Coke"

Ask for either way... both trade-marks mean the same thing.

CA 9.

Need to lose a little weight before your wedding?

Slim Fast

CA 10.

Millions of germs will die.

CA 11.

Cut by Shampoo Planet

Shampoo Planet products considers hair and customer satisfaction, expressed as flowers in a vase, impeccably cut.

CA 12.

Top interior

Offers you don't think twice about

CA 13.

For a country

that rediscovered its colors

this summer 
CA14.

We turn ants into Aints

CA15.

Not your average dessert.

Get a taste of the difference.

Treat yourself well.

Creamy. Cool. Collected. Red Mango's frozen yogurt is a nutritious dessert that transforms average into trendy, hip and smooth. No longer will be brownie mixes, cookie dough rolls and buckets of ice cream represent your indulgence. Now there's a good reason to break free from your routine. Finally, you can say no to average.

CA 16.

Makes other snacks look scary.

Dunkin' Smoothies with real fruit, vitamin C, and low fat yogurt.

America runs on Dunkin'.

CA 17.

C. Jacks

Chicken Carbanara

is a rich combination of chicken, bacon, garlic, pepper, and fettucini noodles, tossed with our own parmesan alfredo sauce, made from scratch when you order.

Complete with a house salad, there's not a better meal in Prairie Village for under $\$ 10$.

CA 18.

Multigrain now available. The new addition to our range of tasty baked breads.

Eat fresh.

CA 19.

Real fries in a fake world.

Our fries start each day as whole, premium potatoes. They're fresh cut and cooked in sunflower oil with no preservatives or coatings. What you get is real goodness and great taste. At New Yourk Fries you really can indulge wisely.

Real, Fresh, Fries.

CA 20.

Grow healthier.

Want to be healthy like Derek Rose? Not only can you feel from exercise and playing sports but eating healthy will take you to the next level. Eating fresh products is a healthier choice than that greasy, fatty, unhealthy fast food. So stop by Growing Power to try some of the locally grown, tasty, healthy, fresh produce.

CA 21.

Brewed with tropical rainwater from one of the few places on earth that still has tropical rainwater.

CA 22.

The same as iPhone

but cheaper!

Samsung Galaxy SII

CA 23.

Where can you find a chair made in 1924 ?

Our modern section

What's new at Hoggie's? Absolutely nothing

Because if it was good enough for grandma's bum, it's good enough for yours!

CA 24.

Save on Postage 
You could, but why would you?

Your prospects are looking for new ways to manage business operations and expenses.

Let's show them how.

CA 25.

Pour on the power to help you heart and lower cholesterol.

Silk is made from one of Nature's perfect Proteins to help you stay strong, and delivers a smooth vanilla taste that keeps you deliciously satisfied.

Silk strength in every pour.

CA 26.

Why have a good day when you can have a great day!

Don't settle for less than great- we wouldn't. Unibic Cookies. Real cookies from Australia. Made with the finest imported oats, sinfully rich chocolate chips, the choicest and creamiest butter. Not to mention, perhaps the most advanced baking technology in the country. Making them richer and tastier than any other mere biscuit. So bite into some of the finest cookies ever made. Bite into a great day!

Unibic Cookies.

You deserve a Great Day!

CA 27.

A is for Apple.

It's the first thing you should know about personal computers.

Discover the special thrill of personal computing- with Apple! It's a home computer, a business computer, a classroom computer, your computer. No wonder tens of thousands have already chosen Apple. Join the excitement in your local computer store. Call for the one nearest you.

CA 28.

When everyone depends on you to stay awake.

Diamond Coffee

CA 29.

Tea Time

Trying to catch flies with chopsticks

Save time for what really matters.

Hot Pocket Pizza. Ready in 1 min 15s.

CA 30.

LG HOM-BOT Vacuum Cleaner

House cleaning is no longer in your hands.

CA 31.

Gatorade always wins!

Rehydrate, Replenish, Refuel

CA 32.

Lotus and Coffee, always together.

The original caramelized biscuit

CA 33.

Don't be the weakest link in the information security chain.

CA 34.

Its here. The new iPhone 3G.

Almost everything you want, for more than you want to pay.

CA 35. 
The barriers to virtualization fall away.

The virtual. The physical.

You can command them both.

How far will you take virtual? 


\section{APPENDIX B}

Images of Social and Commercial Ads

Social Ads

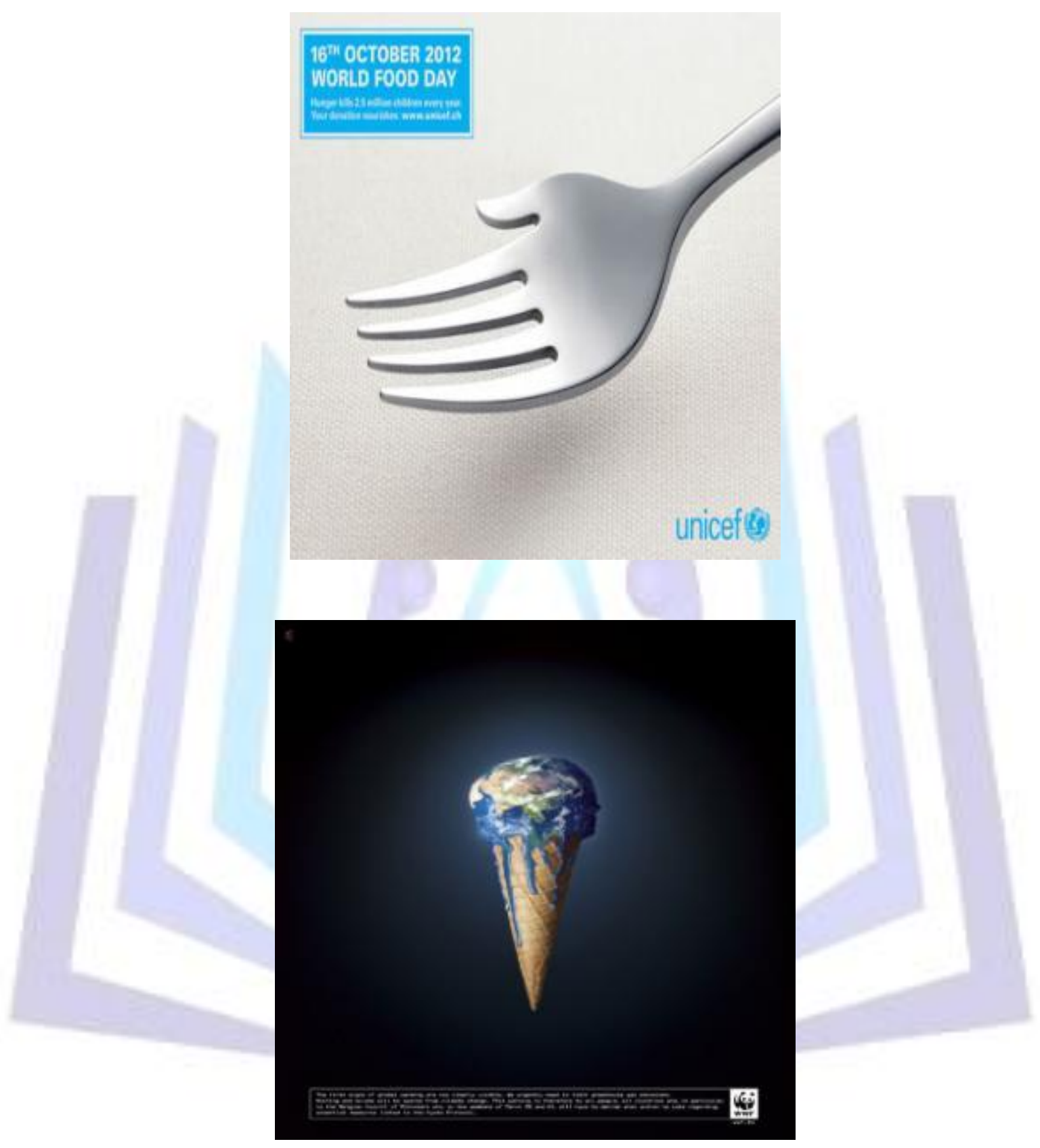



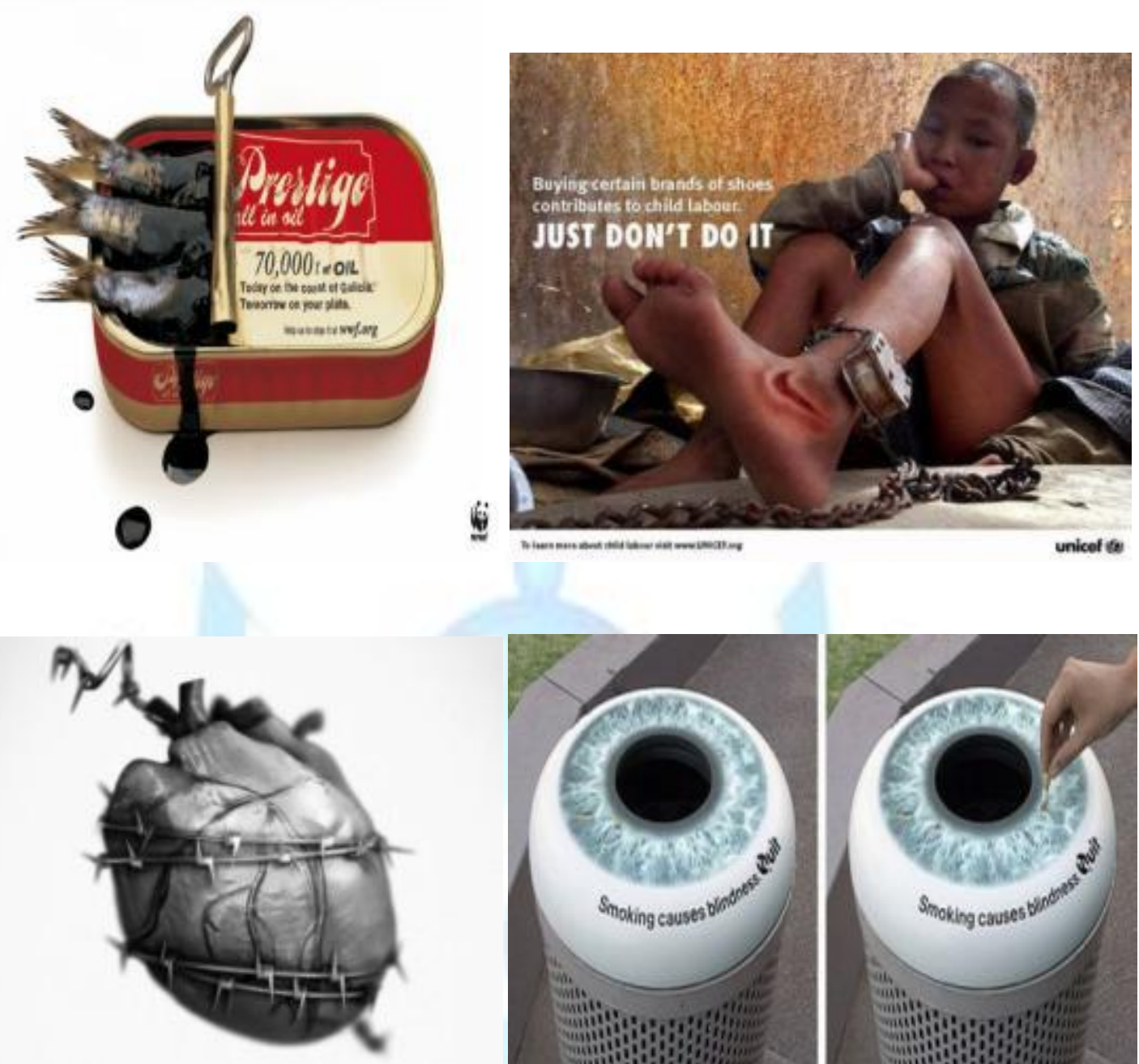

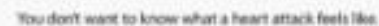
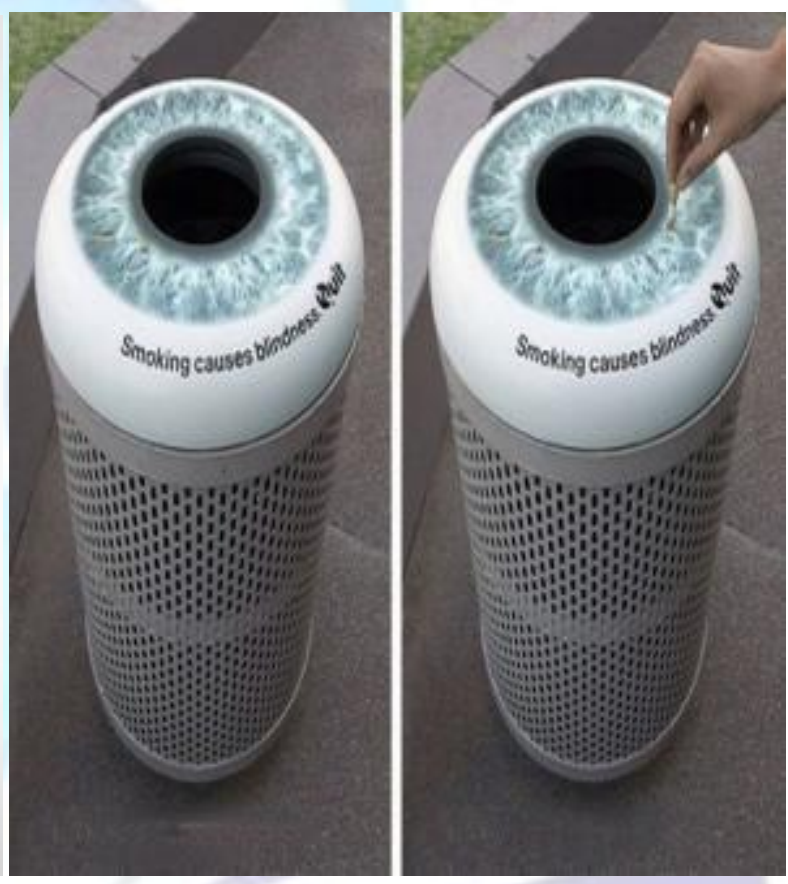

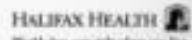


ISSN 2348-3024

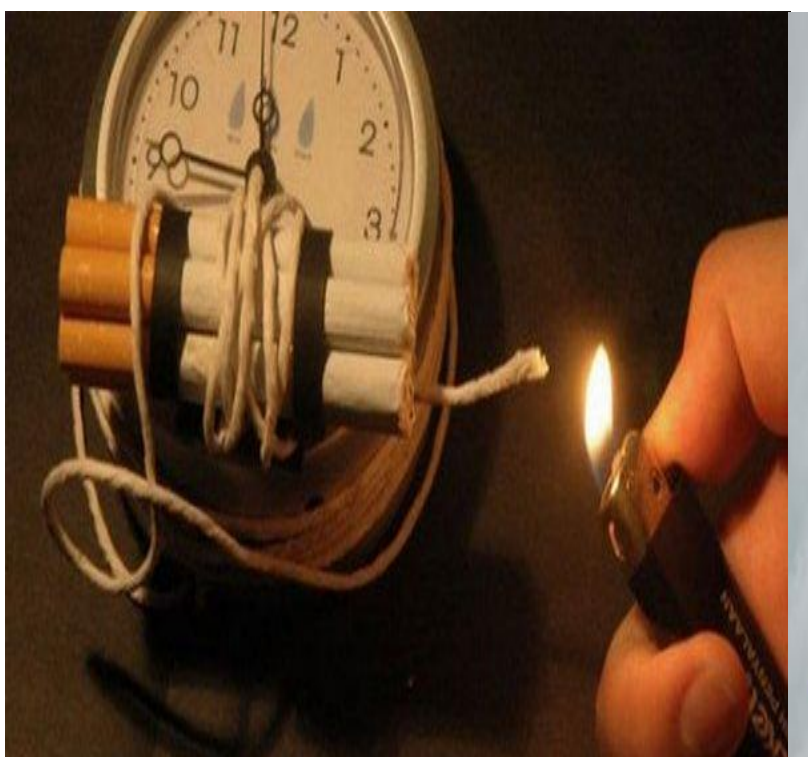

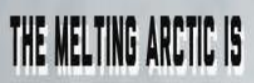

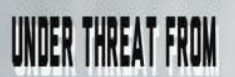

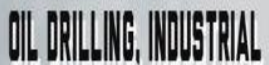

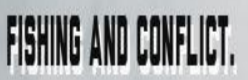

61

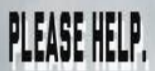

: suln:

EVER BREATH YOU TAKE WLL EVERTUALL Y OESTROY YOUR FUUURE
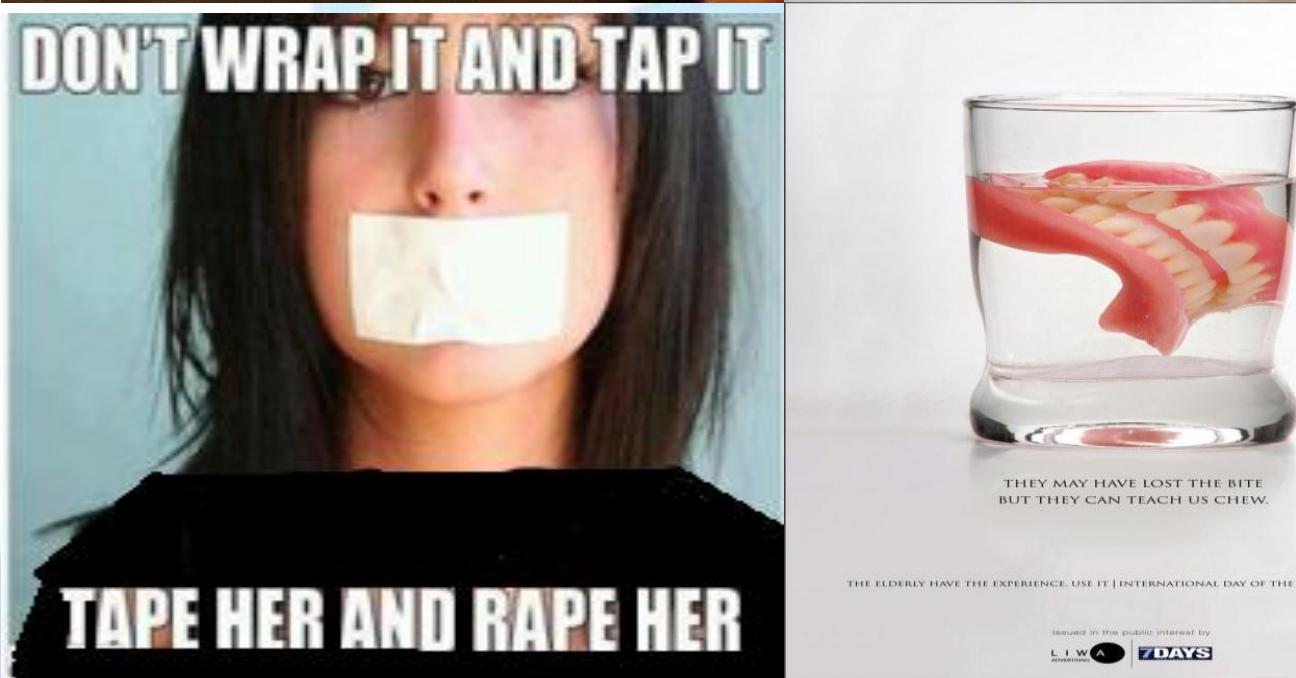

THEY MAY HAVE LOST THE BITE

un एures
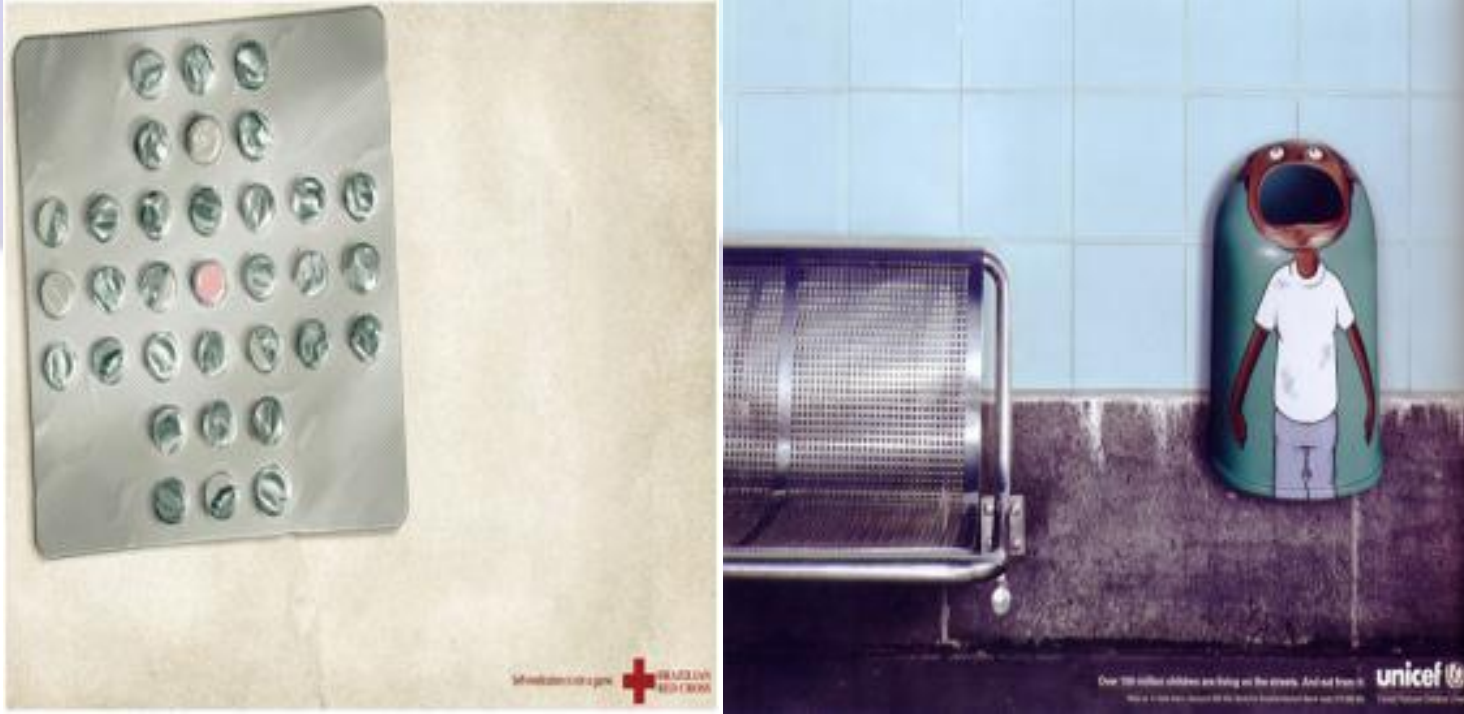

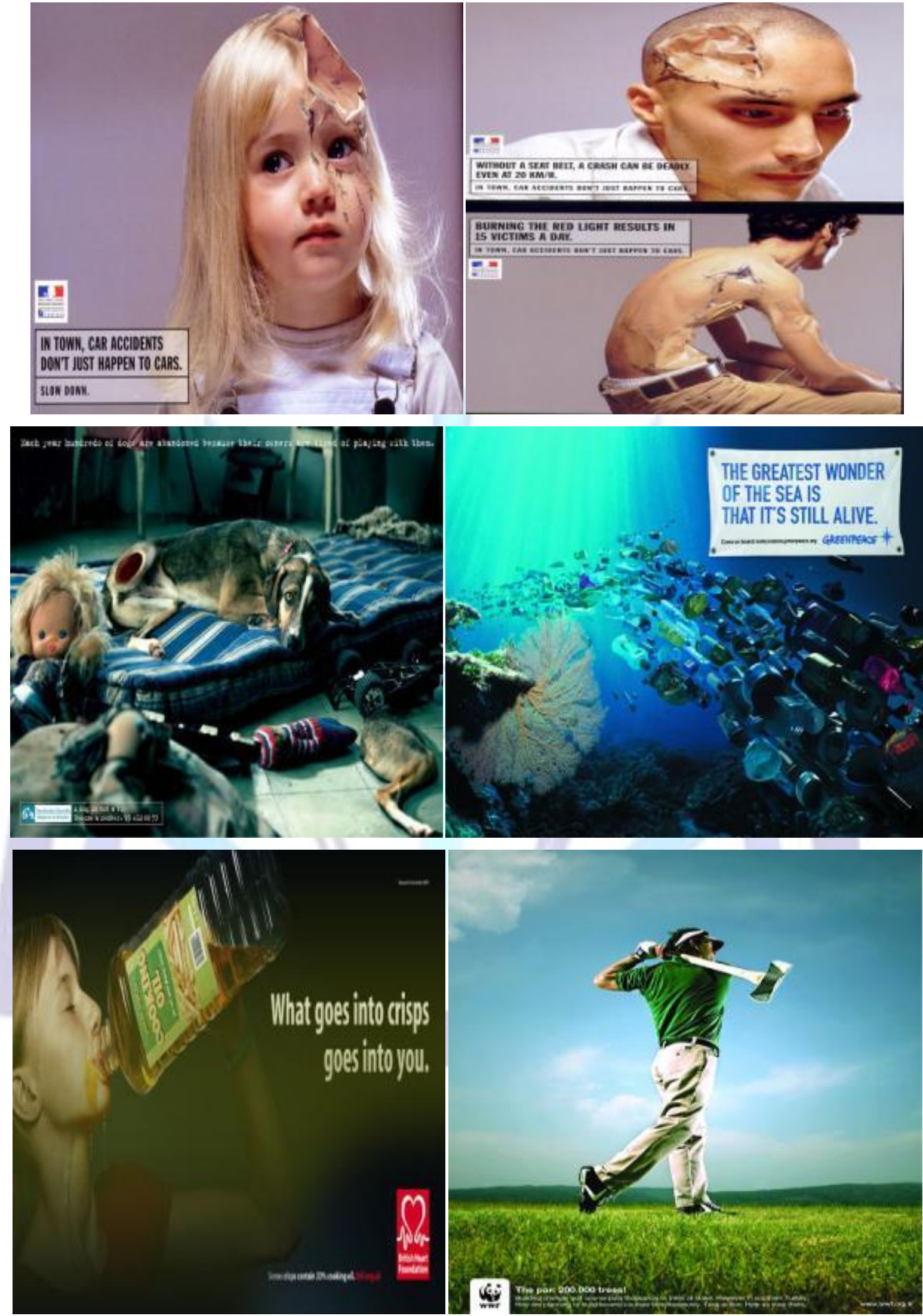

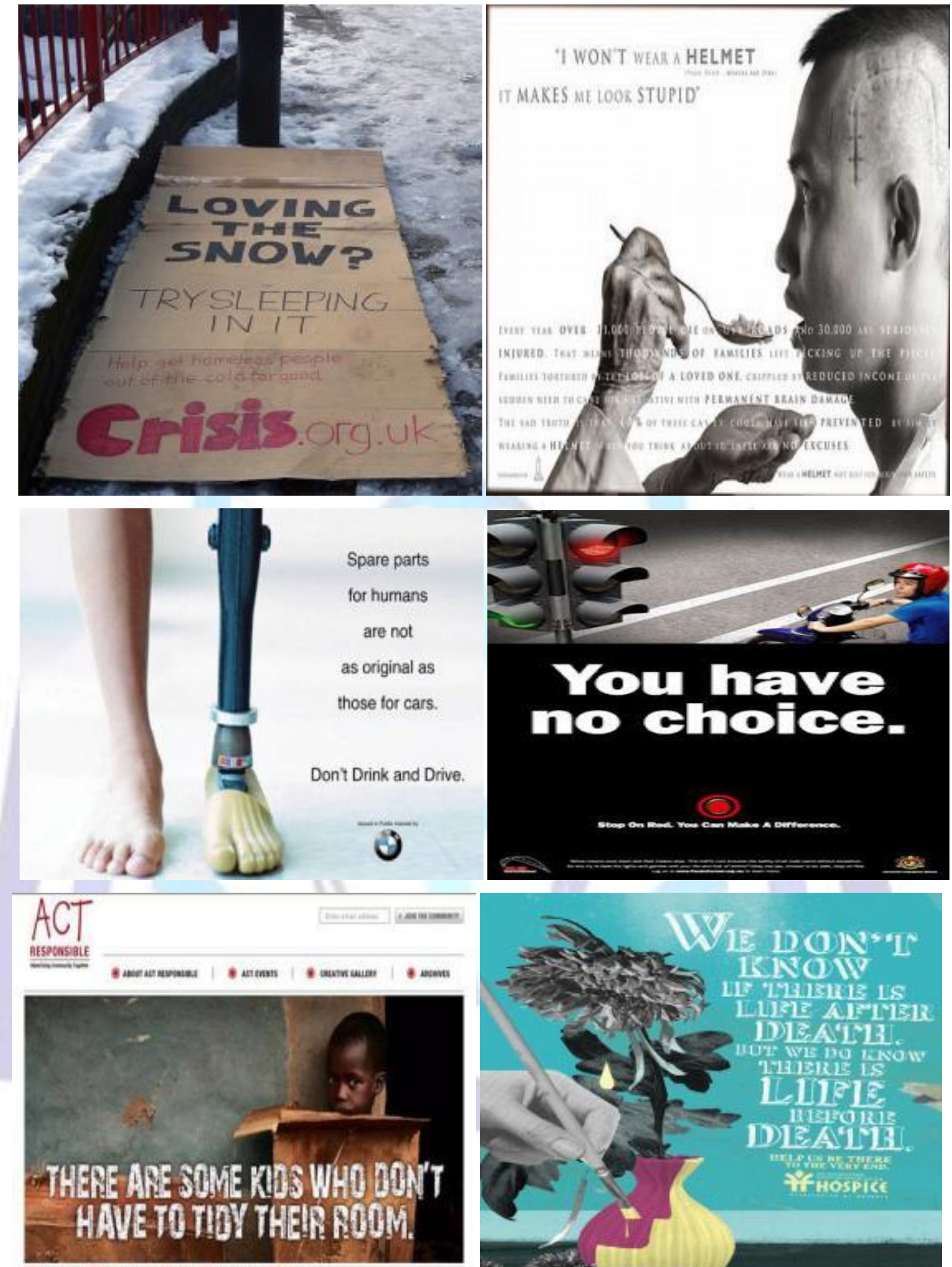

Fu
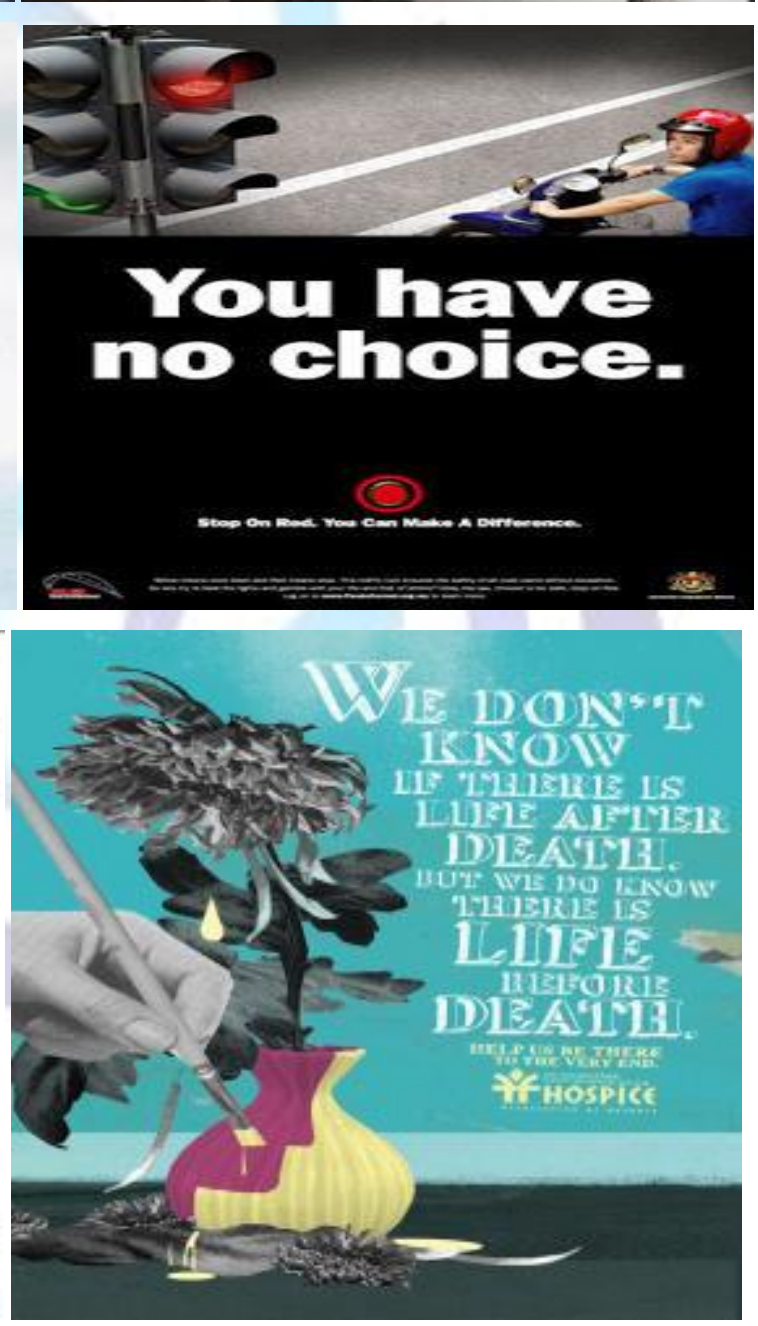

Federating, promoting and inspiring responsible communication. 

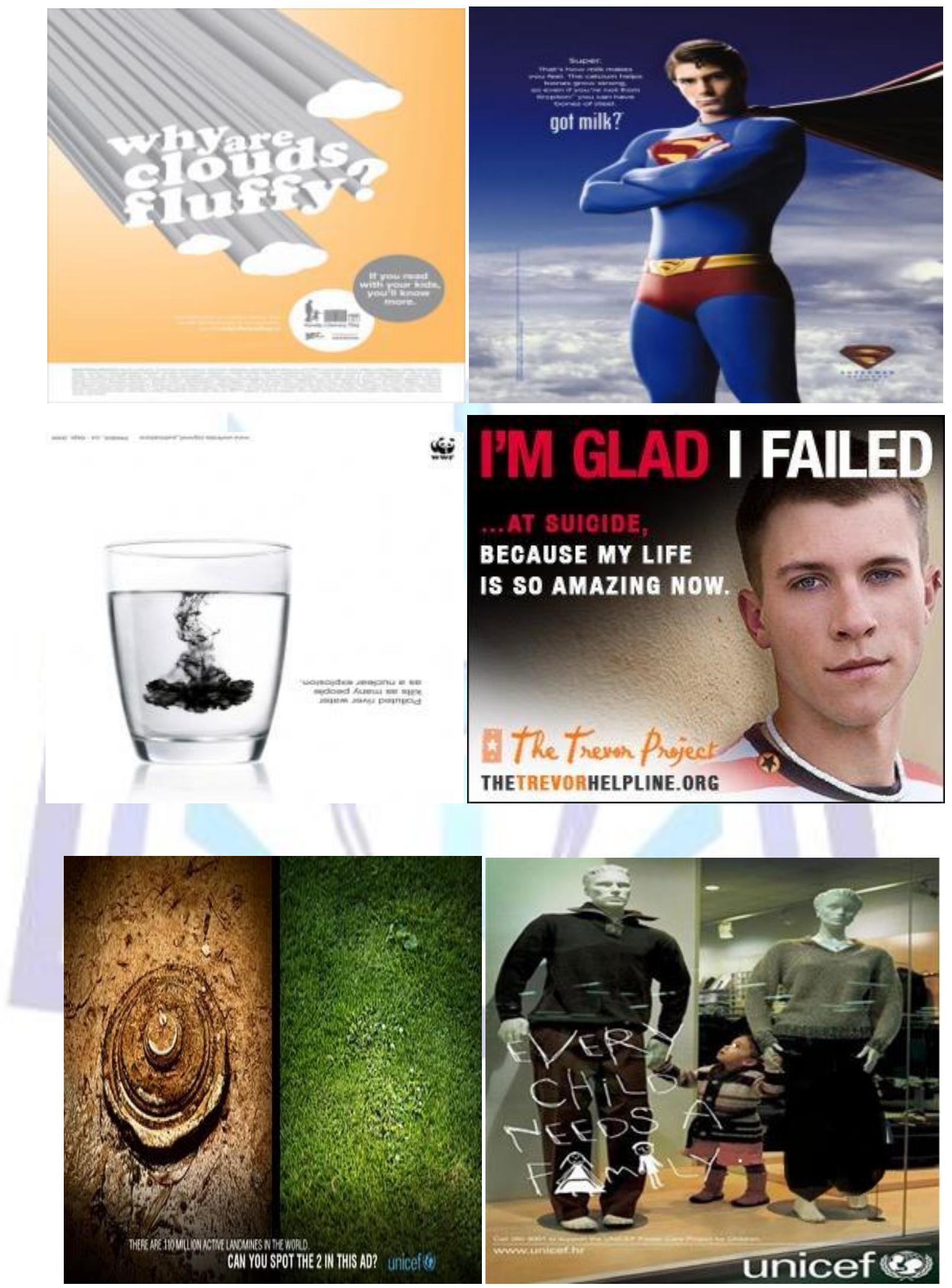

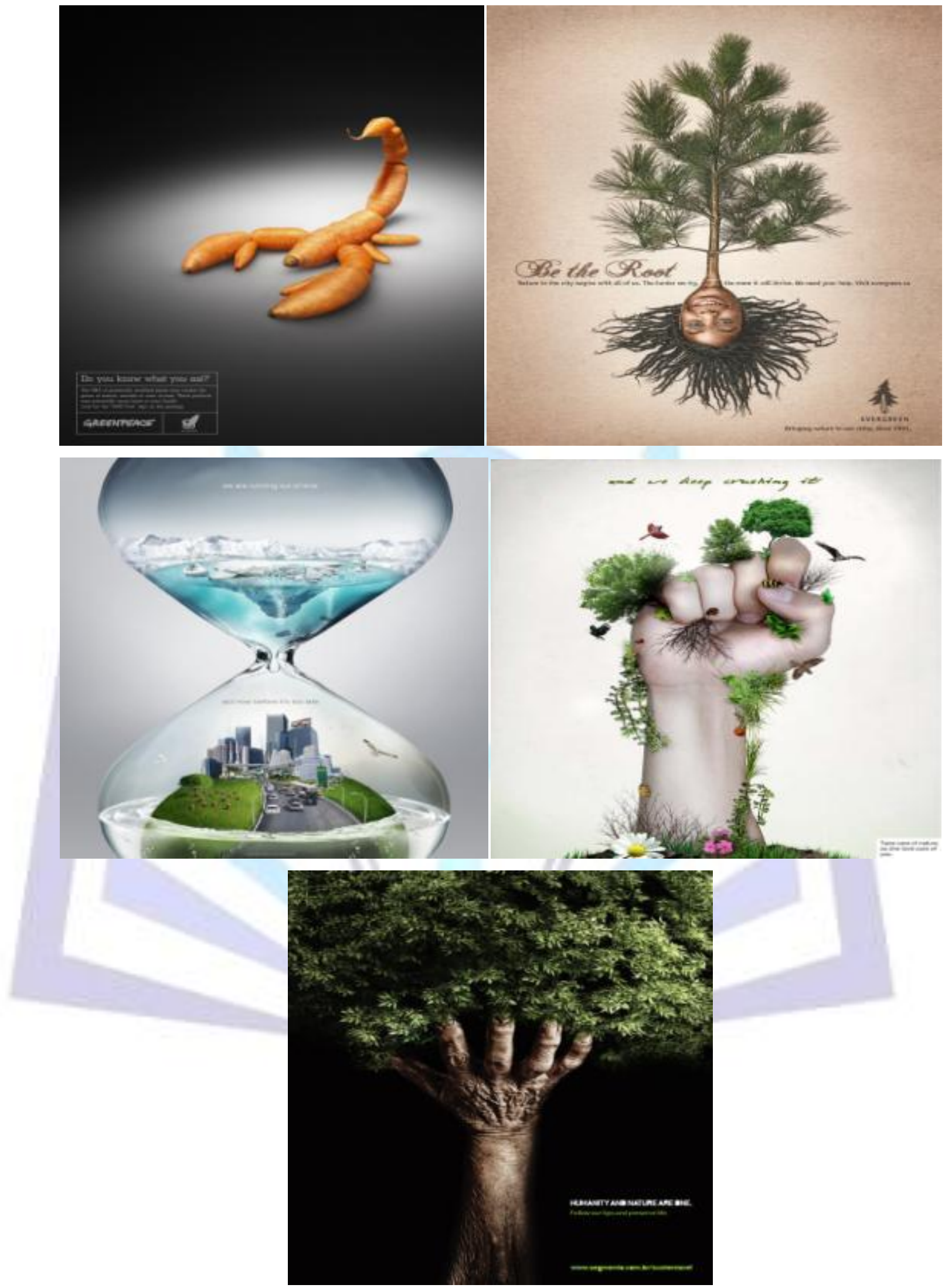
Commercial Ads
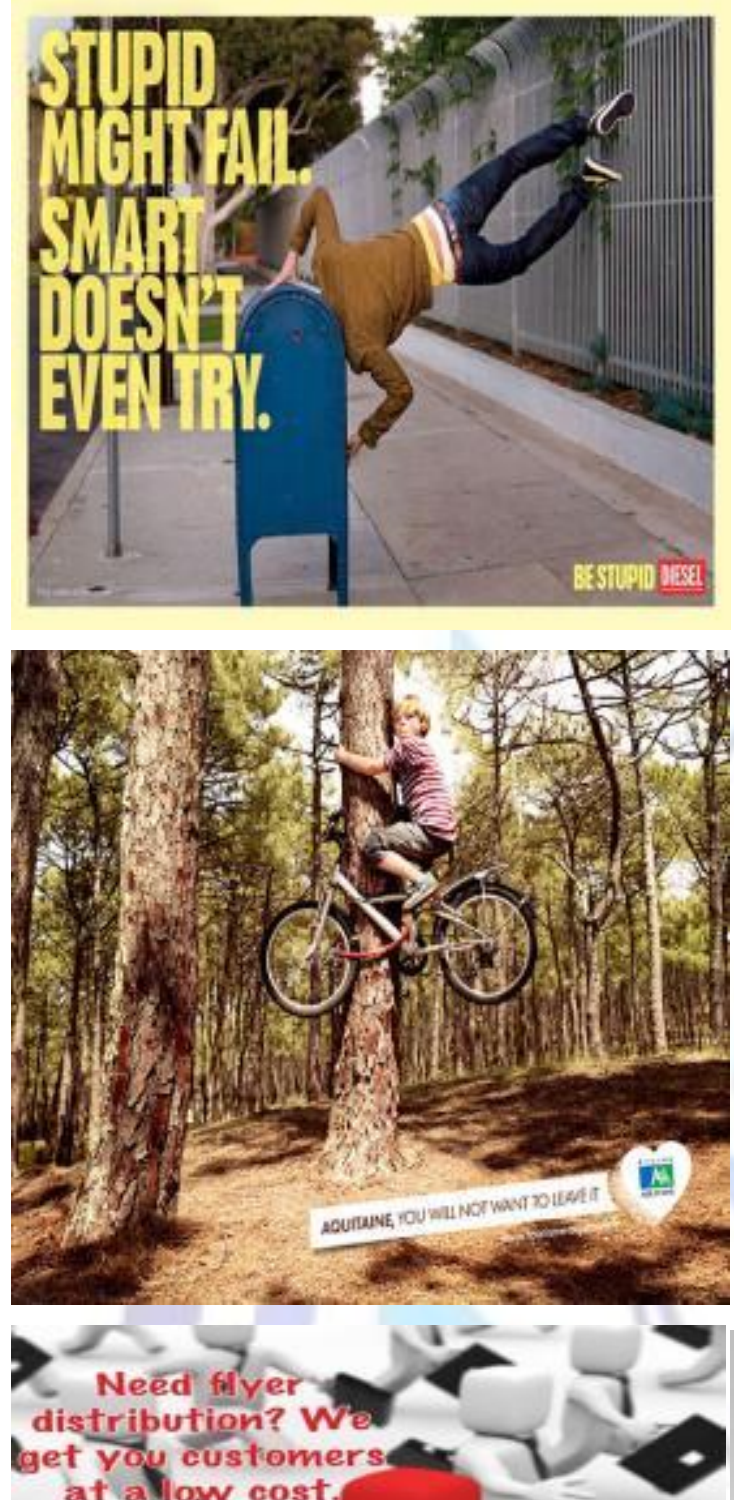
get you customers

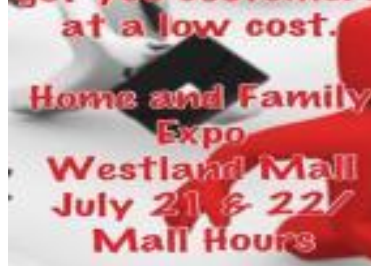

Join our clientele call $305-322-$ 3279
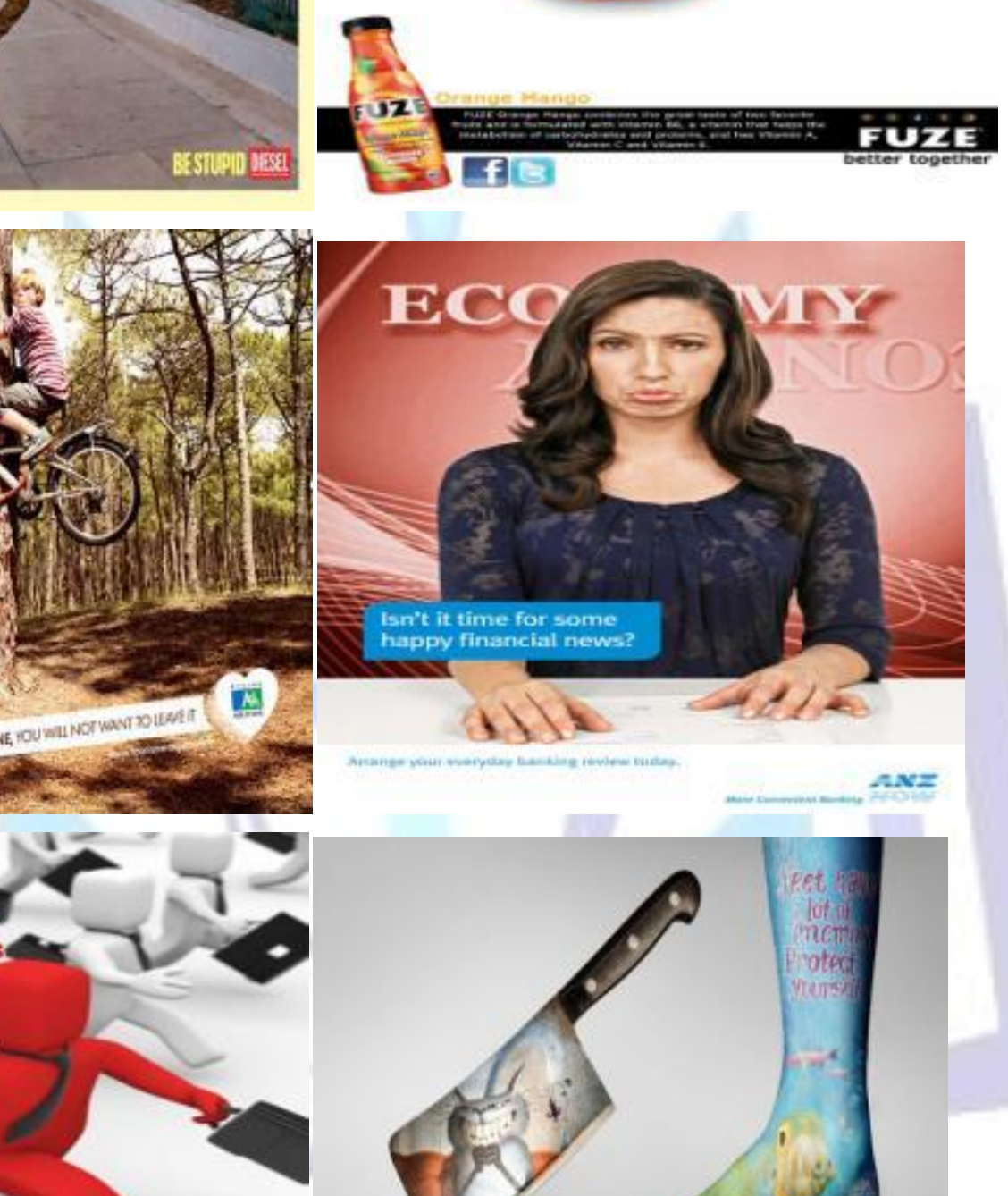

Nature Wasn't Up To The Challenge.

we were.

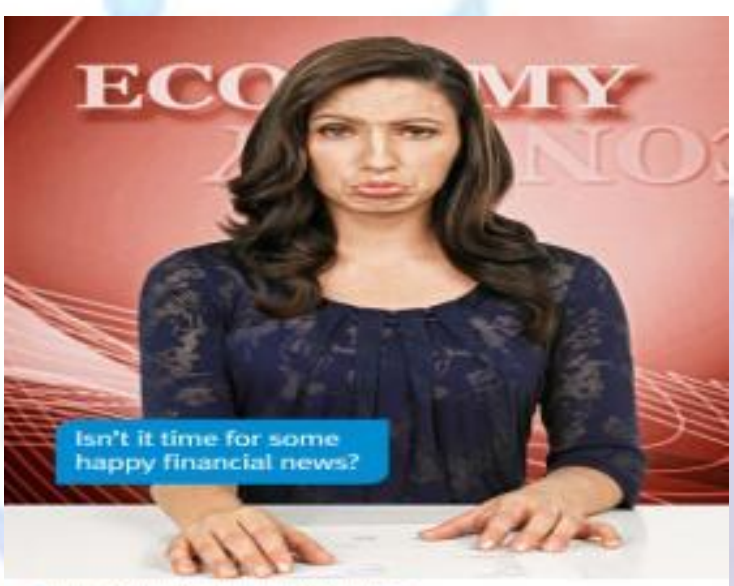
ave

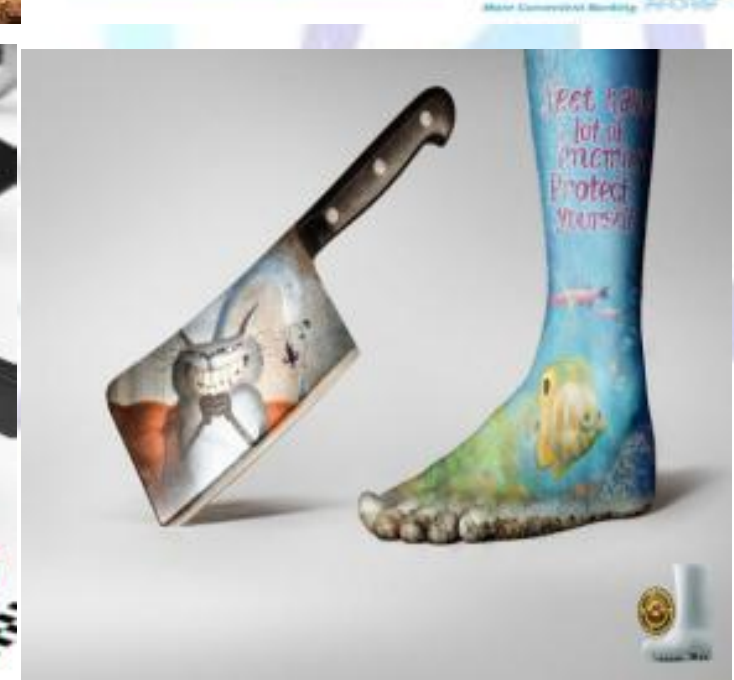



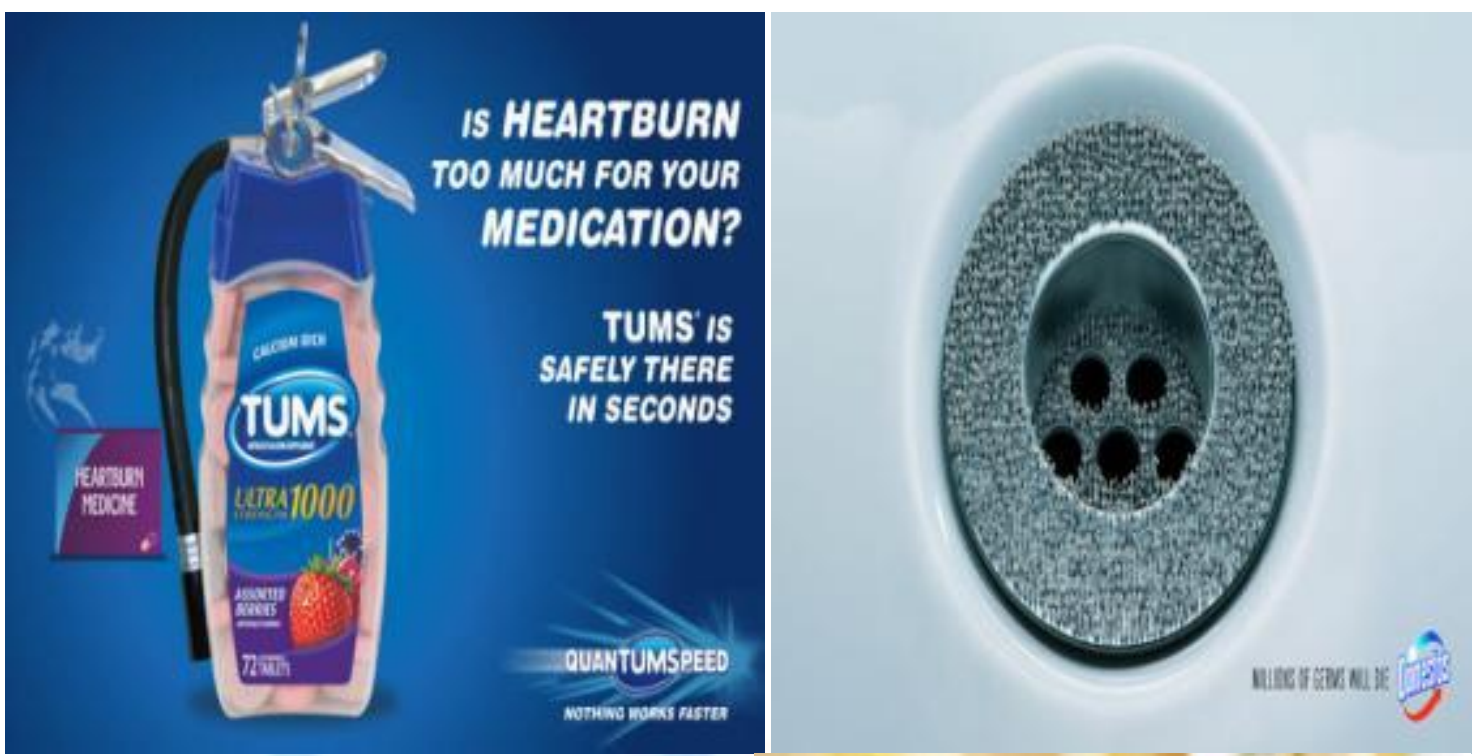

CONTINUOUS QUALITY IS QUALITY YOU TRUST

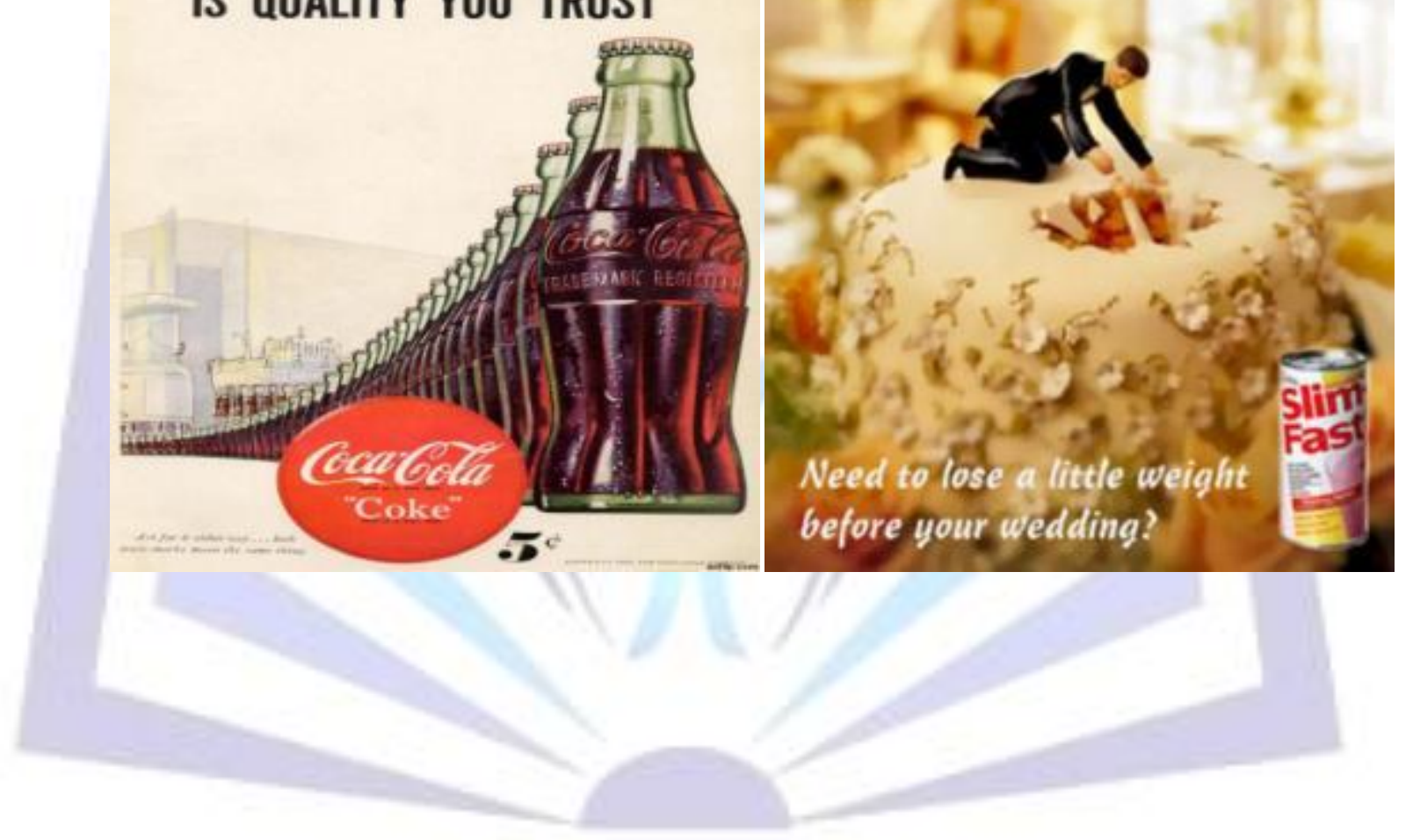



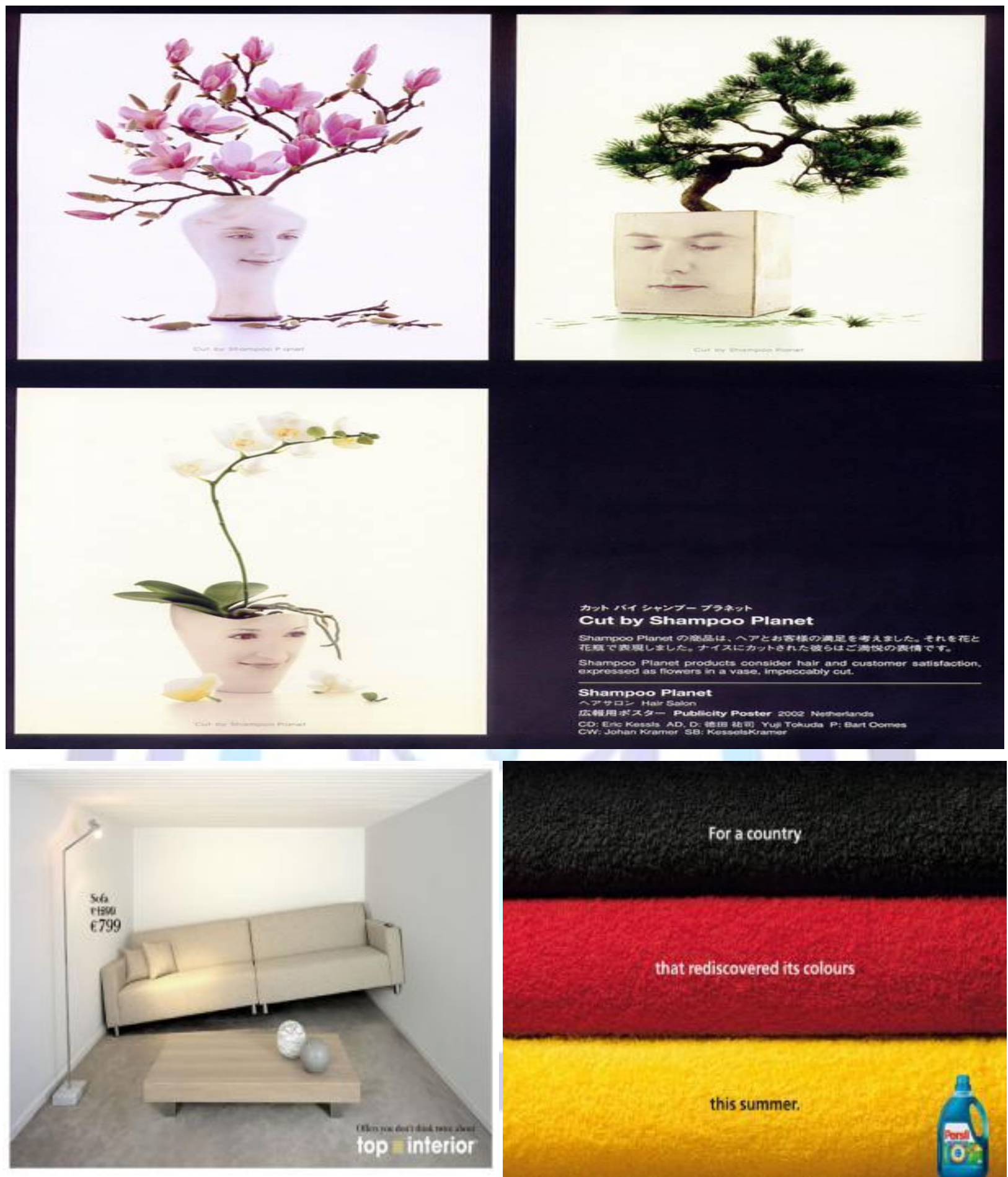


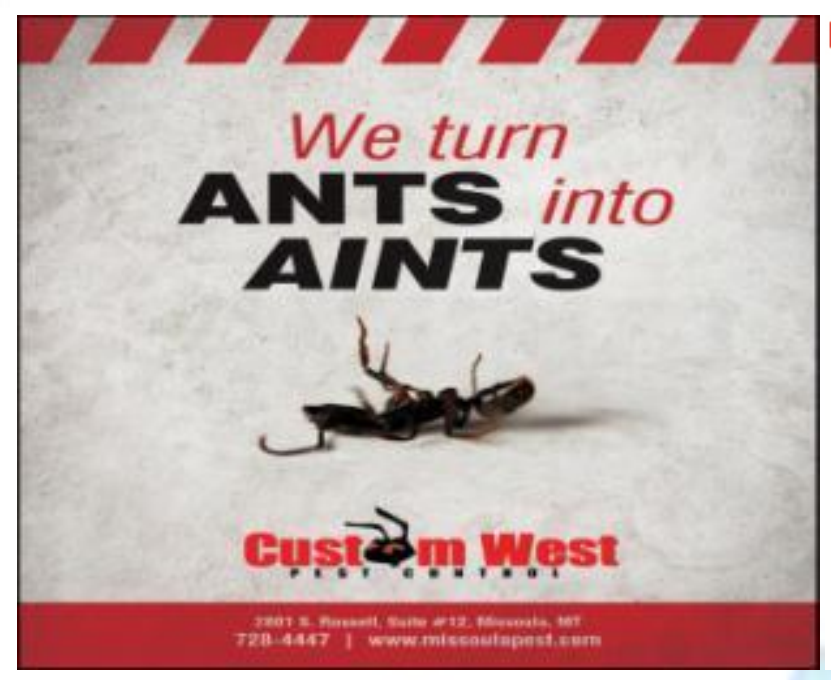

Not Your Average

Dessert.
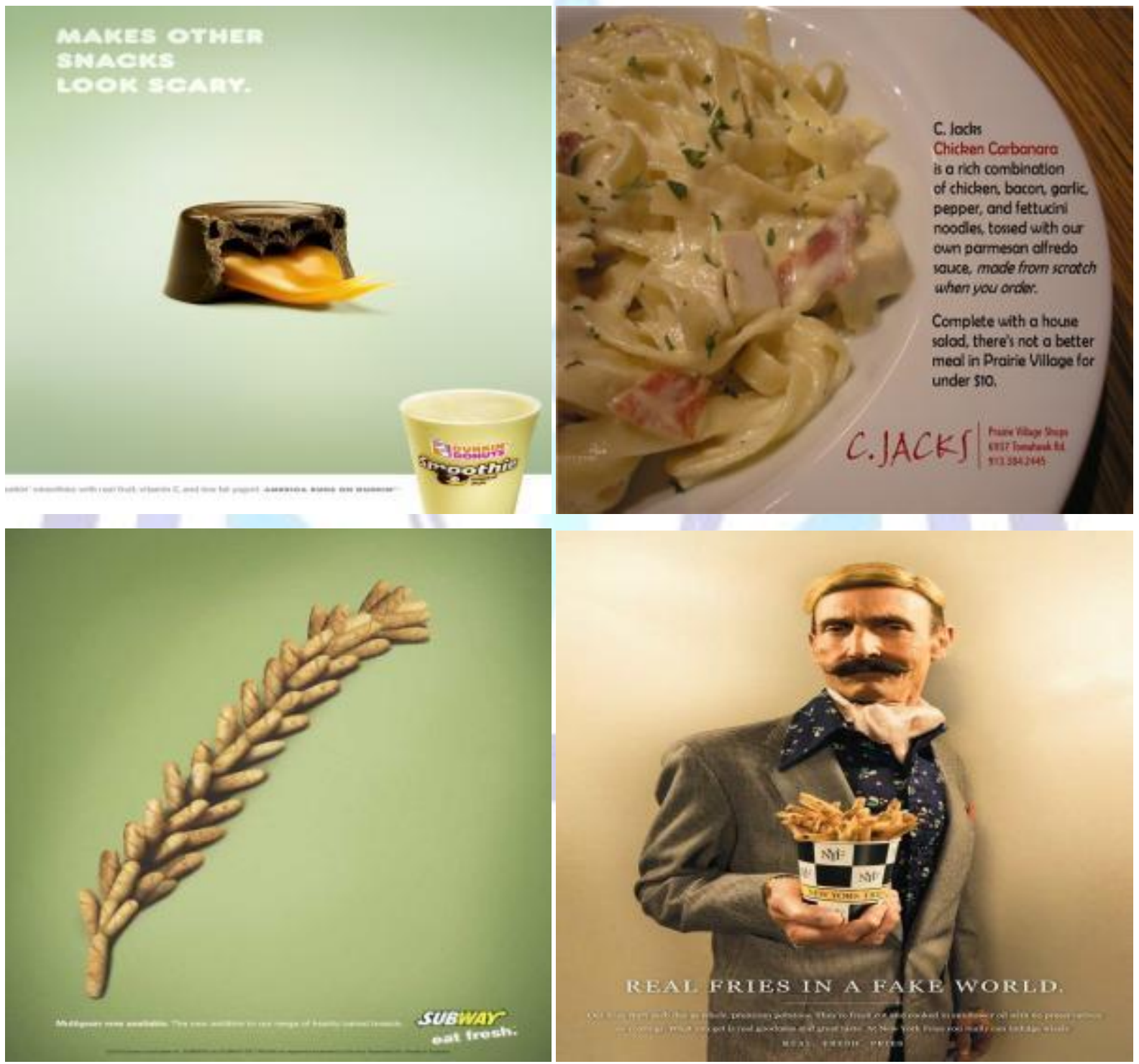

Get a Taste of the Difference.
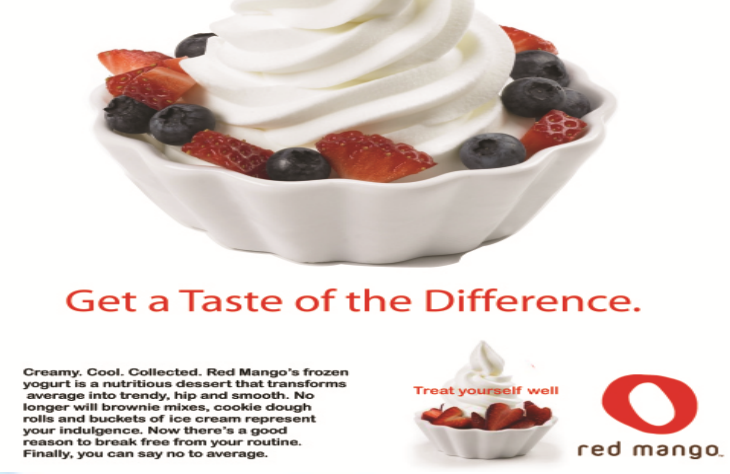


\section{Grow Healthier.}
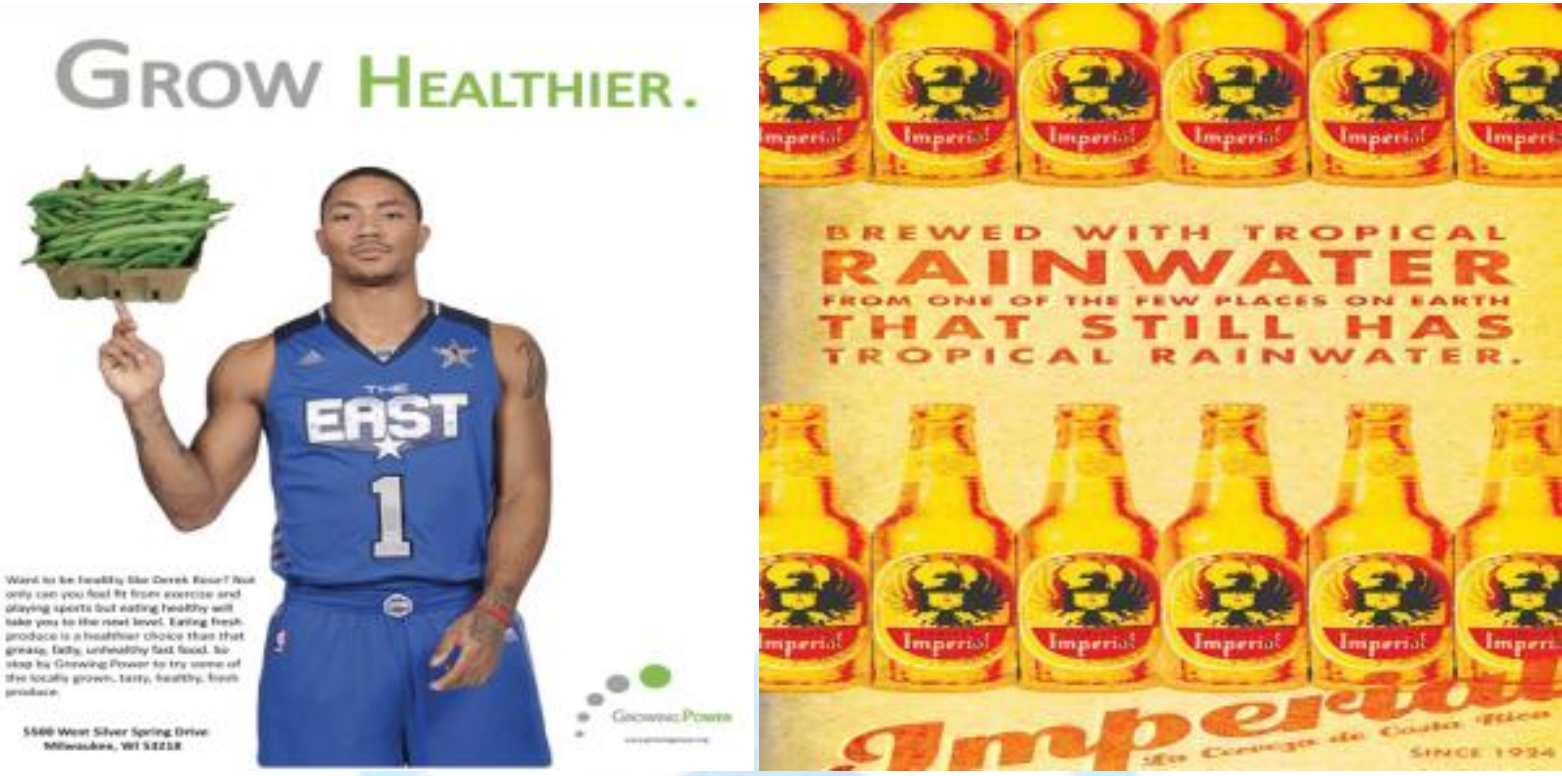

BREWED WITH TROPICAL

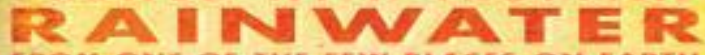
FHOM ONE OF NHS FEW WLACES OM EAKTH

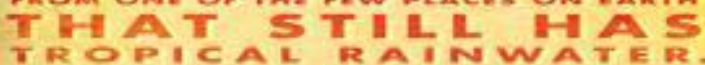
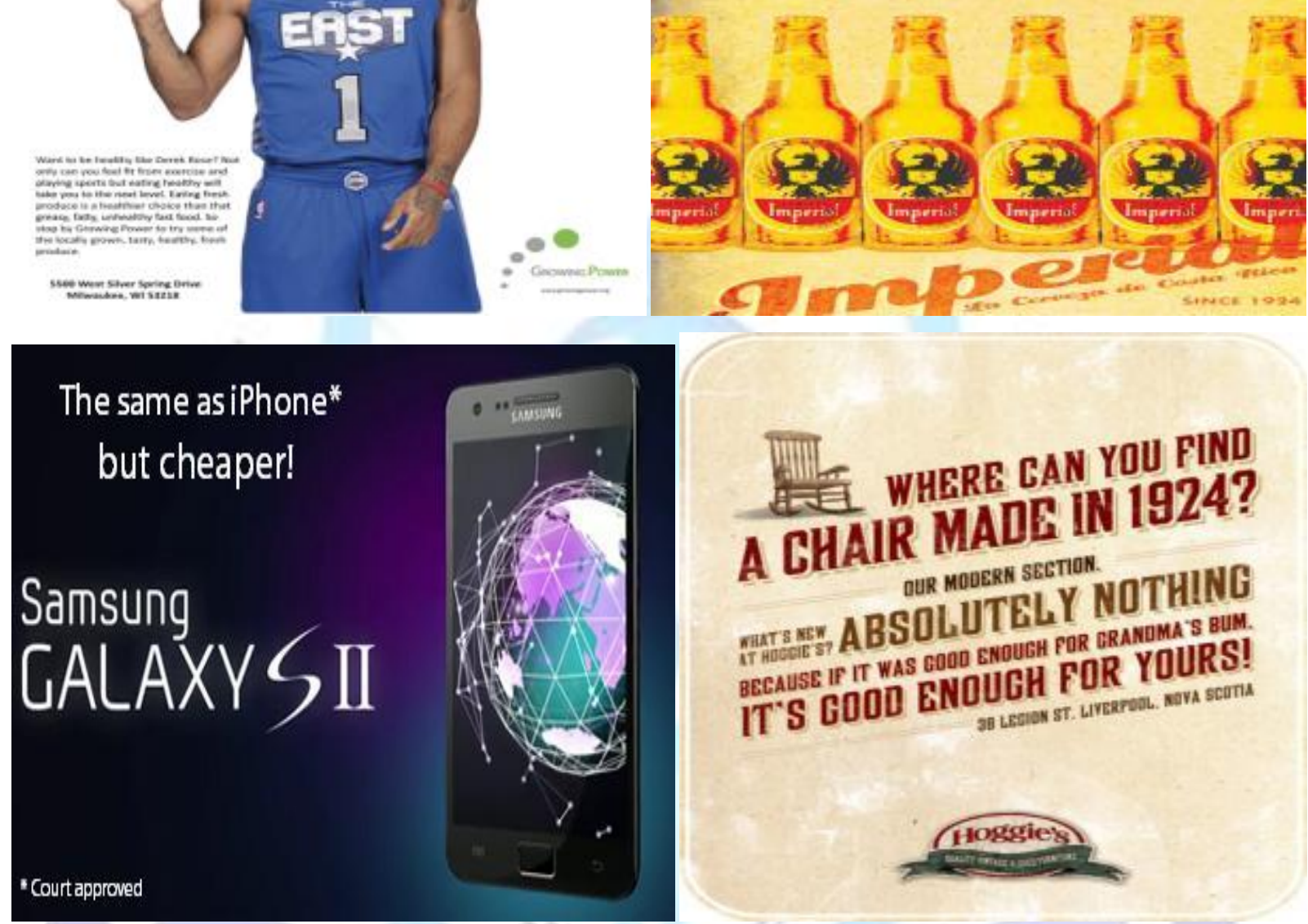

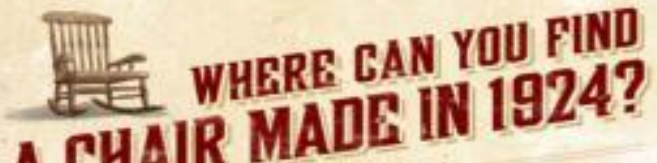
A CHAIR MADL aUR MOOERN SEETION. mats aser, ABSOLUTEL IT HAUSE If IT WAS GOOO ENOUGH POROR YOURS! IT'S GOOD ENOUGH FUR YOLR Bava scorth
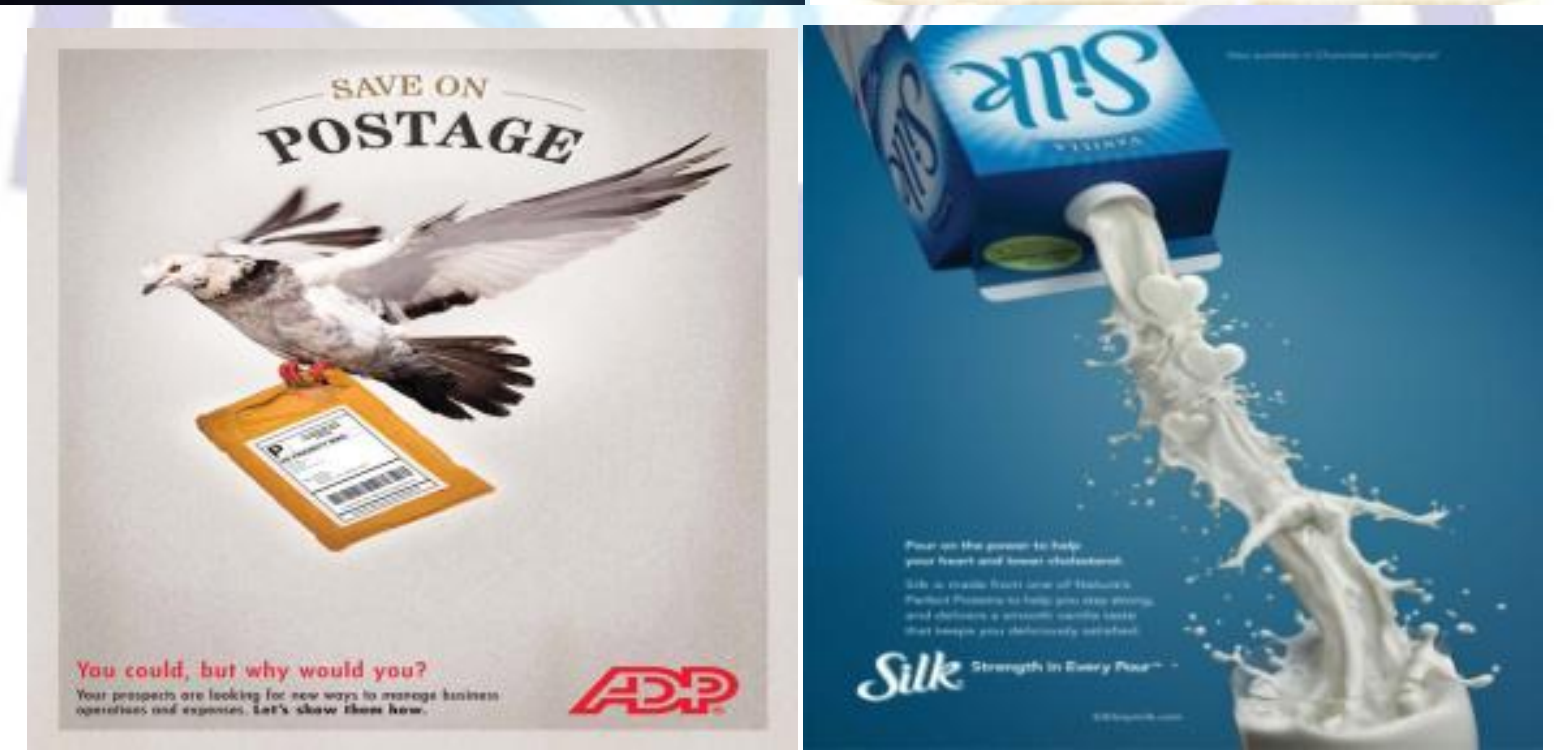

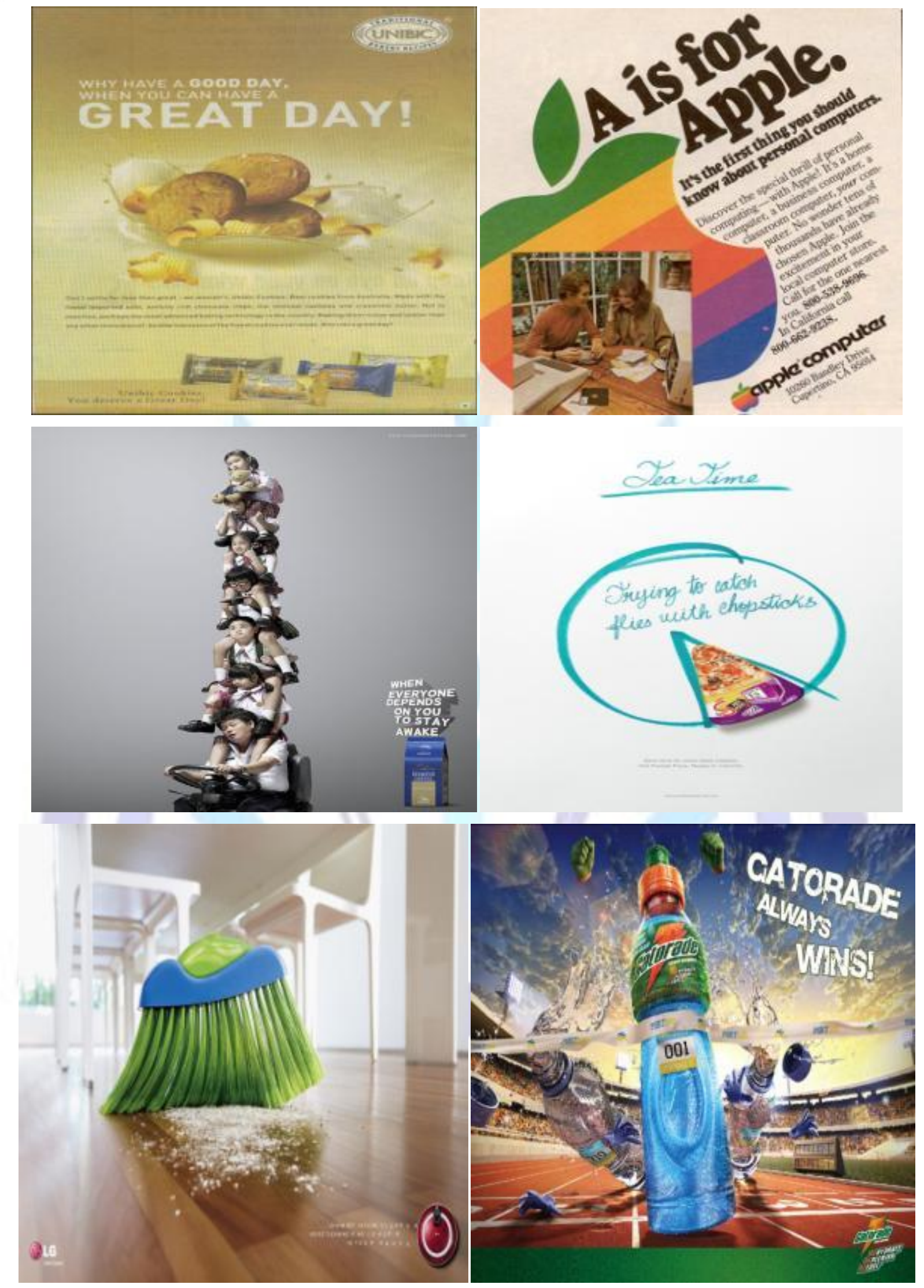


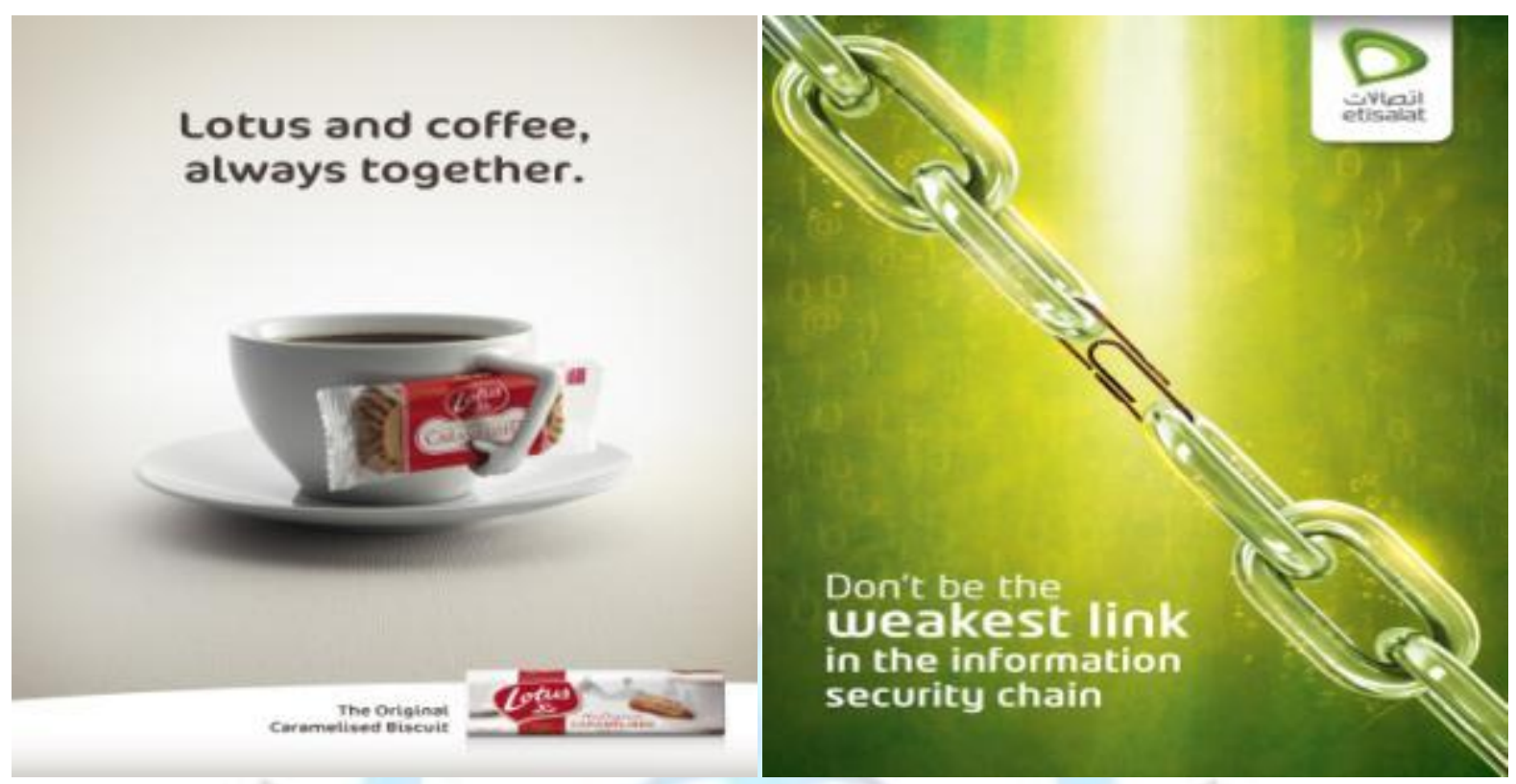

It'shere. The newiPhone3G.

Almost everything you want for more than you want to par.
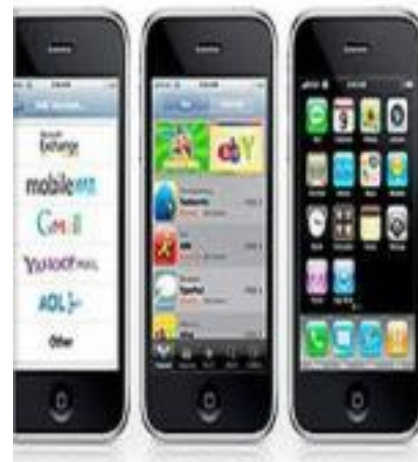

sumpruyken
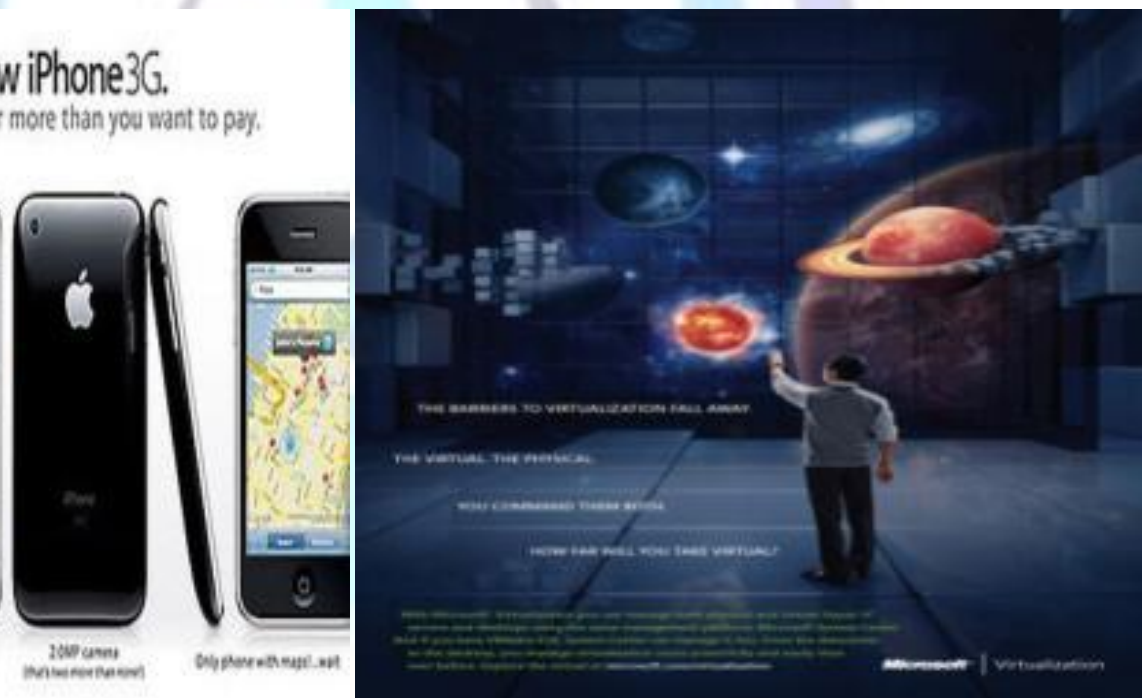


\section{APPENDIX C}

\section{Links Social and Commercial Ads Gathered from Through the Internet}

(All the Ads Were Retrieved from the Internet in June and July 2013)

SA 1.

http://www.unicef.org/nutrition/index 28825.html

SA 2.

http://www.unicef.org/search/search.php?q en=child+labour+nike\&go. $x=1 \& g o . y=5$

SA 3.

http://www.zuzafun.com/creative-wwf-campaigns

SA 4.

http://www.ads-ngo.com/tag/labour/

SA 5.

http://pelfind.com/photos/33187/30-inspirational-print-advertisements

SA 6.

http://koikoikoi.com/2010/02/best-creative-anti-smoking-ad-campaigns/

SA 7.

http://thedesigninspiration.com/articles/top-45-creative-anti-smoking-advertisements/

SA 8.

http://greenpeaceblogs.org/2012/11/08/free-tickets-to-award-winning-documentary-chasing-ice/ SA 9.

http://www.womenactionmedia.org/examples-of-gender-based-hate-speech-on-facebook/

SA 10.

https://www.google.de/search?sa=N\&hl=en\&tbm=isch\&tbs=simg:CAQSZRpiCxCo1 NgEGgllCgwLELCMpwgaPAo6CAES FNcGywbKBvsHzwafB 1AHqAfvB-

kHGiC1J0yr75V6d9IUePSXWYap 1nBOWmRmWbrbBKat|2ZFVwwLEl6u 1ggaCgolCAESBFMx3p8M\&ei=8kcWUsK8Eon Rsga6x4GYBw\&ved=0CCkQ2A4oAQ\&biw=1280\&bih=699\&q=cleaning\%20dentures\%20liwa\%20advertising

SA 11.

http://adsoftheworld.com/media/print/brazilian red cross pill

SA 12.

www.bestadsontv.com/client/1122/

SA 13.

roadsafety.co.za/page/147

SA 14.

http://www.funinstore.com/2011/01/12-non-commercial-ads-with-social-responsibility-part-2/

SA 15.

http://laughingsquid.com/puppies-are-not-toys-campaign-urges-people-to-avoid-pet-store-dogs/

SA 16.

http://adsoftheworld.com/media/print/greenpeace ocean defenders 1

SA 17.

http://metro.co.uk/2006/09/22/eating-crisps-is-like-drinking-oil-261264/

SA 18.

www.worldwildlife.org/

SA 19. 
www.pinterest.com/phs77girl/our-homeless-sisters-and-brothers/

SA 20.

www.creativeadvertisingworld.com/i-wont-wear-helmet/

SA 21.

https://www.drinkanddrive.co.uk/campaigns.php

SA 22.

www.printads101.blogspot.com/

SA 23.

www.akvablog.wordpress.com/2010/04/19/

SA 24.

http://adsoftheworld.com/media/print/hospice association of ontario life goes on

SA 25.

www.adsoftheworld.com/.../abc canada literacy foundation guy/

SA 26.

www.enewsi.com/news.php?catid=190\&itemid=9287/

SA 27.

www.adsoftheworld.com/media/print/wwf india water/

SA 28.

www.crowdrise.com/fundraiserelise/

SA 29.

https://www.google.de/url?sa=t\&rct=i\&q=\&esrc=s\&source=web\&cd=2\&cad=rja\&ved=0CDIQFjAB\&url=http\%3A\%2F\%2Fth omaswebbphoto.blogspot.com\%2F2010 0701 archive.html\&ei=MnYWUo3NEYbDhAeJalHoBw\&usg=AFQjCNEUS5YV 7R1IT2wQeLeO7eaGnKv5rA

SA 30.

www.flickr.com/photos/28551873@N05/2692304391/

SA 31.

http://designyoutrust.com/inspirations/do-you-know-what-you-eat/

SA 32

www.donorpowerblog.com/donor power blog/2009/04/

SA 33.

http://sofreshsogreen.tumblr.com/post/11932007731

SA 34.

http://www.google.de/imgres?hl=en\&bih=699\&biw=1280\&tbm=isch\&tbnid=x3dPUywBuGEdRM:\&imgrefurl=http://www.cou riermail.com.au/

SA 35.

www.adsoftheworld.com/media/.../segmento humanity and nature are one/

CA 1.

www.behance.net/Discover/Patricia Morin/

CA 2.

www.diesel.com/be-stupid/

CA 3.

www.creativeadawards.com/you-will-not-want-to-leave-it/

CA 4.

www.advertolog.com/brands/anz-bank/ 
CA 5.

www.hdiphonewallpapers.us/3D-phone-wallpapers/

CA 6.

WWW.theinspirationroom.com/daily/.../sete-leguas-boots-enemies/

CA 7.

http://designerhubin.blogspot.de/2012/10/30-inspirational-print-advertisements.html

CA 8.

www.vintageadbrowser.com/coke-ads-1940s/2/

CA 9.

WWW.super-trainer.com/funny-weight-loss-ads/

CA 10.

WWW.doblelol.com/bacteria-funny.htm/

CA 11.

http://desigg.com/daily-design-inspiration-4-120-creative-advertisements/

CA 12.

WWW.adsoftheworld.com/media/print/top interieur sofall

CA 13.

WWW.creativeads.blogspot.com/2007/02/persil.html//

CA 14.

https://www.google.de/search?sa=G\&hl=en\&bih=699\&biw=1280\&q=dead + ant\&tbm=isch\&tbs=simg:CAQSZRpiC $x$ Co $1 \mathrm{NgE}$ GgllCgwLELCMpwgaPAo6CAESFL4GvAatBsQGxQbGBp8G 1wWZBrsGGiD0aGmb95WKppese2D3hkuGtpAVTJiGWM OpeLNehcFGCQwLEI6u 1ggaCgolCAESBB84ROMM\&ei=eVEYUvTKCIfCtQbk8IHAAw\&ved=0CCgQwg40AA

CA 15.

https://www.facebook.com/pages/The.../160451270634827/

CA 16.

www.kabeerkhan.com/10-brilliantly-photoshopped-print-ads/

CA 17.

www.behance.netDiscover/Dustin Turnerl

CA 18.

http://smashinghub.com/20-creative-advertisements-of-famous-fast-food-chains. htm

CA 19.

www.newyorkfries.com/about_nyf/ad_museum/reall

CA 20.

https://www.facebook.com/pages/Derrick.../424714530322/

CA 21.

http://www.dailydesigninspiration.com/advertisements/young-rubicam/imperial-beer/

CA 22.

www.samsung.com/us/documentation/tmo/.../virtualguide/

CA 23.

www.advertolog.com/...and.../modern-section-13870305/

CA 24.

www.coloribus.com/adsarchive/prints/adp-postage-13480205/

CA 25. 
http://designerhubin.blogspot.de/2012/10/30-inspirational-print-advertisements.html

CA 26.

https://www.google.de/search?sa=G\&hl=en\&q=creatine+powder\&tbm=isch\&tbs=simg:CAQSXxpdCxCo1NgEGgllCwwLEL CMpwgaNgo0CAESDq0EhQSDBIYEpwSABYQEGiD0XzRWSpN2Z7WBvlavmTmkikGZfgiomZrWJplaSrhQmQwLEI6u 1 ggaCgolCAESBFH2g80M,isz:s\&ei=P2oYUufkE8zOswaNmoCYCQ\&ved=0CCoQ2A4oAg\&biw=1280\&bih=699

CA 27.

www.macmothership.com/gallery/gallery1.html

CA 28.

www.adsoftheworld.com/.../diamond coffee school bus driver/

CA 29.

http://adsoftheworld.com/creative/marco versolato

CA 30.

www.advertolog.com/lg/print-outdoor/dust-15565955/

CA 31.

http://www.google.de/imgres?hl=en\&biw=1280\&bih=699\&tbm=isch\&tbnid=DvcUw52j8id0sM:\&imgrefurl=http://thefinishedb ox.com/inspiration/print/bestadvertisementposters/\&docid=KaZQm8L4hnA tM\&imgurl=http://thefinishedbox.com/wpcontent/uploads/2011/02/advertisementsedition1

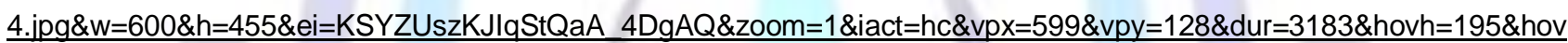

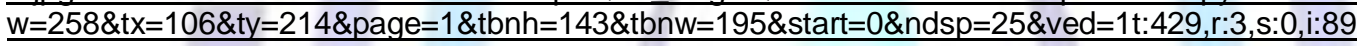

CA 32.

www. lotusbakeries.com/

CA 33.

https://www.google.de/search?hl=en\&bih=699\&biw=1280\&tbm=isch\&oq=\&gs $\quad$ l=\&q=the\%20weakest\%20link\%20in\%20inf ormation \%20security\#fp=35676ceca0e0005f\&hl=en\&q=the+weakest+link+in+information+security+advertisement \&tbm=is $\underline{\mathrm{ch}}$

CA 34.

www.ifitshipitshere.wordpress.com/

CA 35.

http://advertlover.com/node/635.

\section{Authors' Bioghraphy}

Somayyeh Motallebi is MA in English Language Teaching from Islamic Azad University, Maragheh . Her current research interests cover Discourse analysis.

Davud Kuhi, PhD in English Language Teaching, is a teacher of applied linguistics issues in Islamic Azad University, Maragheh. His current research interests include Academic Discourse Analysis and Critical Discourse Analysis. 